\title{
An Ethnobotanical Survey of a Dryland Botanical Garden and Its Environs in Kenya: The Mutomo Hill Plant Sanctuary
}

\author{
Fredrick Munyao Mutie $\mathbb{D}^{1,2,3}$ Lun-Lun Gao, ${ }^{1,2}$ Vivian Kathambi, ${ }^{1,2,3}$ \\ Peninah Cheptoo Rono, ${ }^{1,2,3}$ Paul Mutuku Musili, ${ }^{4}$ Grace Ngugi, ${ }^{4}$ Guang-Wan Hu $\mathbb{D}^{1,2}$ \\ and Qing-Feng Wang $\mathbb{D}^{1,2}$
}

${ }^{1}$ CAS Key Laboratory of Plant Germplasm Enhancement and Speciality Agriculture, Wuhan Botanical Garden, Chinese Academy of Sciences, Wuhan 430074, China

${ }^{2}$ Sino-Africa Joint Research Center, Chinese Academy of Sciences, Wuhan 430074, China

${ }^{3}$ University of Chinese Academy of Sciences, Beijing 100049, China

${ }^{4}$ East Africa Herbarium, National Museums of Kenya, P.O. Box 451660-0100, Nairobi, Kenya

Correspondence should be addressed to Guang-Wan Hu; guangwanhu@wbgcas.cn

Received 3 November 2019; Revised 30 January 2020; Accepted 10 February 2020; Published 17 March 2020

Academic Editor: Victor Kuete

Copyright (C) 2020 Fredrick Munyao Mutie et al. This is an open access article distributed under the Creative Commons Attribution License, which permits unrestricted use, distribution, and reproduction in any medium, provided the original work is properly cited.

\begin{abstract}
Mutomo hill plant sanctuary is a ten-hectare piece of land in Kenya listed as a botanical garden under the Botanical Gardens Conservation International, originally established in 1964 with the aim of conserving indigenous flora from destructive anthropogenic activities. This paper presents ethnobotanical documentation of medicinal plants of Mutomo hill plant sanctuary and its environs. An ethnobotanical survey was carried out in Mutomo hill plant sanctuary and its environs with 48 herbalists aged between 32 and 96 years from July 2018 to February 2019 using a semistructured open-ended questionnaire. The plants were collected through random surveys with each herbalist in different ecotypes around the villages and within the Mutomo hill plant sanctuary. The Relative Frequency of Citation (RFC) for each species reported was calculated to determine the plant species frequently collected. In total, 68 different plant species distributed in 28 families and 54 genera were reported. The frequently used plant families were Leguminosae (13 species), Lamiaceae (6 species), and Euphorbiaceae (6 species). Shrubs (37\%) and trees (34\%) were the dominant growth habits reported. The most cited plant species were Cassia abbreviata Oliv. (RFC = 0.63), Acacia nilotica (L.). Delile $(\mathrm{RFC}=0.54)$, Strychnos heningsii Gilg $(\mathrm{RFC}=0.46)$, and Aloe secundiflora Engl. $(\mathrm{RFC}=0.31)$. Root $(19$ species $)$ and bark (19 species) were the frequently collected plant parts. Infectious diseases (33) and digestive system disorders (24) were reported to be managed with the majority of the plant species. This study contributes to safeguarding the traditional knowledge on medicinal plants in the study area, which is useful in appreciating and acknowledging the cultural heritage of the Kamba people from the local perspective of Mutomo area in Kenya. It also adds to the knowledge base and documentation of medicinal plants, which is useful information as potential data for drug development.
\end{abstract}

\section{Introduction}

The use of plants for medicine has been practiced for many years [1]. This culture has developed through trial and error and has for a long time been passed orally from one generation to another $[1,2]$. African traditional medicine is the oldest, perhaps the most diverse mode of treatment and among the less known systems of medicine in the world
[2-5]. Despite the production of synthetic drugs, the utilization of natural organic healing materials for the treatment of diseases has persisted throughout the world [5]. In addition, modern healthcare techniques have been less effective in the treatment of some infectious diseases such as malaria and HIV/AIDS which have affected Africa more than any other part of the world [6]. Furthermore, the use of traditional medicine has been attributed to the high cost and 
inaccessibility of modern healthcare care services compared to the cheap and readily available herbal medicine $[6,7]$. The traditional communities have recently begun to appreciate the effectiveness of modern healthcare services against diseases such as HIV/AIDS leading to a reduction in the number of people relying on traditional medicine [8]. A recent study reported that the use of traditional medicine for health care has declined in Africa and Asia with most of the people turning to modern health care services. For example, just $1.7 \%$ and $1.5 \%$ of the populations studied in South Africa and Ghana respectively reported consulting traditional medical practitioners in the past three years [9]. An overall decline in the use of traditional practices has also been reported elsewhere in South Africa where an analysis of nationally representative population-based surveys from 1995 to 2007 showed that the use of traditional medicine had declined to $0.1 \%$ or less in the past month from $3.6-12.7 \%$ in just over a decade [10]. It has been estimated that at least $90 \%$ of the population in Kenya has used medicinal plants for health care at some point in life [11]. However, Awiti [12] reported that only $7.56 \%$ of the respondents studied consulted "nonmodern" health care providers while just $0.15 \%$ consulted traditional healers, further suggesting that the use of traditional medicine is also on the decline in Kenya. The reduction in the use of traditional medicine is probably due to the increase and cultural acceptability of modern health care services [10]. Ethnomedicinal studies in East Africa have however revealed that medicinal plants are used by many populations for various health problems such as reproductive and gynecological problems $[13,14]$, management of infectious diseases such as HIV/AIDS and malaria [15-17] and as antidotes against snake bites $[18,19]$. In addition, medicinal plants are sold in some urban areas as a source of income [20, 21].

In Kenya, about $80 \%$ of the landmass is covered by arid and semiarid areas [22]. Drylands of Kenya play a significant role in the country's formal and informal economy, yet they have not been incorporated in the country's conservation regimes making it difficult to get a true picture of their status and trends of their biodiversity. In addition, little support and advocacy have been directed to such areas [23]. Based on the Flora of Tropical East Africa, the flora of Kenya is comprised of 6,293 indigenous vascular plant species [24] out of which over 5,000 plant species reportedly occur in drylands [25]. An estimated 1,200 plant species in Kenya are reported to have a medicinal value [26]. In Kenya, ethnobotanical studies involving various ethnic groups have been done $[16,17,21,27-44]$. The local communities who use natural resources have interacted with the biodiversity over the years and hence have accumulated important traditional knowledge regarding their use [40]. The aging of the older generations and the change of lifestyles that have seen the younger generations take up formal education have left much of the indigenous knowledge undocumented and on the verge of being lost [45]. In addition, ethnobotanical surveys have not been done extensively in many regions of Kenya [36]. There is therefore a need for appropriate measures to mitigate the current abuse and foster proliferation of the biodiversity in drylands for the benefit of future generations [46].
Like in many other African countries, medicinal plants in Kenya are commonly collected from the wild with poor harvesting methods such as debarking [47]. Such plants are diminishing as a result of unsustainable harvesting and destruction of habitats [48]. It is on account of such destructive human activities that the early botanists in Kenya considered the need to set aside areas for conservation of important indigenous plant species. Among such areas is the Mutomo hill plant sanctuary which was established in 1964 [49] and gazetted as a botanical garden in 1993 [50]. Despite this, plant diversity loss in such areas is still in progress and is expected to increase with the increase in the human population [46]. The Kenyan wealth of dryland biodiversity and its indigenous knowledge is not well documented [23]. There are various botanical surveys done in Kitui county such as the biodiversity of Kitui hills [46], some ethnobotanical surveys $[34,40]$ and a checklist of the vascular plants of Mutomo hill plant sanctuary [49]. Mutomo hill plant sanctuary is a well-known botanical garden under the Botanical Gardens Conservation International [50, 51]. Despite this, ethnobotanical surveys in Mutomo hill plant sanctuary and its environs have not been done. Since the role of botanical gardens in the conservation of useful plants including medicinal plants is well-known [52], the lack of ethnobotanical data of the sanctuary and its environs justified the need for this investigation. This study brings more understanding of medicinal plant usage and knowledge thereof to the nation as cultural and scientific heritage at a local level. It also informs about plants of economic importance to the world because it adds knowledge of these medicinal plants as potential resources for drug development.

\section{Subjects and Methods}

2.1. Study Area. The study was carried out in Mutomo hill plant sanctuary and its environs. Mutomo hill plant sanctuary is geographically located within the Mutomo division; hence Mutomo division was selected to represent the environs of Mutomo hill plant sanctuary. Mutomo division is located at $38^{\circ} 12^{\prime}$ East and $1^{\circ} 50^{\prime}$ South in Kitui county (Figure 1). Kitui county is largely a low plateau rising from $300 \mathrm{~m}$ above the sea level and interrupted by various inselbergs reaching about $1638 \mathrm{~m}$ above the sea level [53] where the highest altitudes reach about $1800 \mathrm{~m}$ [54]. Generally, the climate of Kitui county varies from arid to semiarid and is characterized by a minimum mean annual temperature varying from $14^{\circ} \mathrm{C}$ to $22^{\circ} \mathrm{C}$ and a maximum mean annual temperature ranging from $26^{\circ} \mathrm{C}$ to $34^{\circ} \mathrm{C}$. There are two rainy seasons where the long rains start from March and end in June while the short rains start in October and end in December with a mean annual rainfall ranging from $250 \mathrm{~mm}$ to $1050 \mathrm{~mm}$ [54]. The low-lying areas receive low rainfall and are extremely hot. The vegetation of Kitui county is characterized by low, stunted, dense thorn bushes with thick undergrowth and occasional baobab trees. Much of the area lacks forests except on the hills [55] where scrublands and wooded bushlands can be found [56] dominated by Drypetes, Combretum, Vepris, and Croton species [46]. The geography of Kitui county is characterized by several 


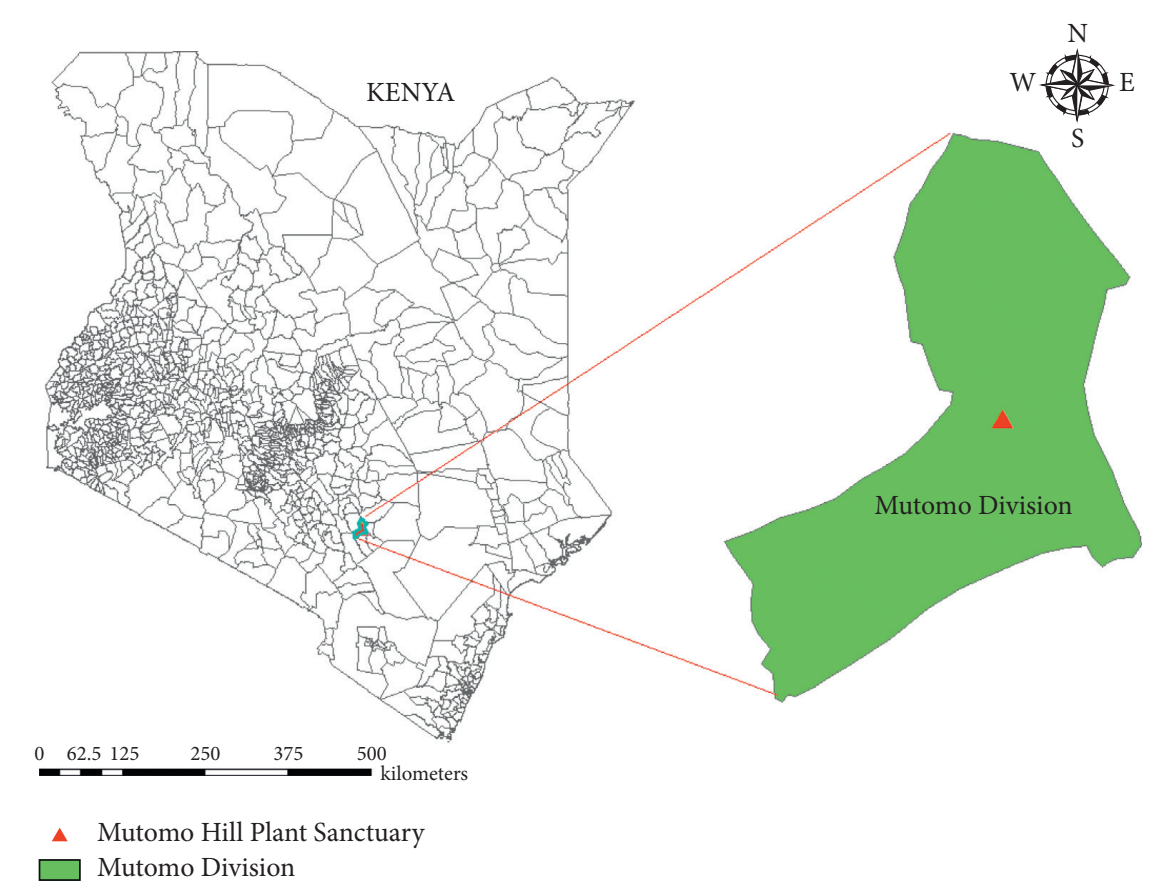

Figure 1: Map of Kenya showing the location of Mutomo division and Mutomo hill plant sanctuary.

hilltops which contain a high diversity of plant and animal species [46]. Such highlands provide a link between the coastal forests and the highland forests, resulting in the survival of unique species adapted to the individual highlands [46, 57]. One of such important highlands is the Mutomo hill plant sanctuary, located 125 miles East of Nairobi. The sanctuary is a ten-hectare piece of land, about $1211 \mathrm{~m}$ in length and rising to an altitude of about $1000 \mathrm{~m}$ from red lateritic plains to worn granitic gneiss $[49,50]$. Its floral diversity is rich and includes succulent and xerophytic plants [49]. The plant diversity of Kitui county is high and is used by the local communities for traditional foods, tisanes, medicines among other uses [53, 57].

Kitui county is inhabited by Kamba people who practice agriculture and semipastoralism [40, 55] which involves growing a variety of crops and keeping livestock [53, 57] where the cattle are kept as a security against famine [58]. Most of the population in the county relies on agriculture for economic income, where the main food crops include maize, millet, sorghum, green grams, beans, peas, cassava, and sweet potatoes [54]. Literature reveals that as early as 1911, the Kitui Kamba traditional way of life was being interrupted by foreign groups including the colonial governments [58]. Despite this, they have conserved their indigenous knowledge on plant utilization and are reportedly one of the ethnic groups in Kenya who have conserved their traditional knowledge on medicinal plants $[40,53]$.

2.2. Ethnobotanical Data Collection and Analysis. The field survey was conducted between July 2018 and February 2019. Prior to the field survey, the herbal practitioners were identified with the help of the local administrative authorities who included the subchiefs of Mutomo division and the rangers at Mutomo hill plant sanctuary. In addition, the herbalists recommended the researchers to other herbalists within the study area. The informants were the herbalists who were practicing traditional medicine at the time of study or those who had reduced working periods due to age or to be involved in other activities such as farming. Interviews were administered in Kamba language, which is the main dialect spoken in the area and later translated into English. Interviews were recorded in semistructured open-ended questionnaires at the homesteads of the herbalists while in some cases, the herbalists met with the researchers at shopping centers or in other appropriate places such as farmlands where some of them collected the medicinal plants. The herbalists first mentioned the medicinal plants they had used and later guided the researchers to the wild where the plants were collected. Interviews with each informant lasted between two to five hours involving field surveys in different ecotypes including hills, forests, and farmlands throughout the six sublocations of Mutomo division and within the Mutomo hill plant sanctuary. Data collected included the demographic information of the informant (name, age, sex, occupation, and level of education) and the botanical information (vernacular name of the plant, its source, parts used, medicinal uses, and methods of drug preparation and administration). For each plant species cited, an herbarium voucher material was collected. Photographs of all the medicinal plants cited were taken to help during identification. Identification was done following the local monographs of the Kenyan flora $[59,60]$ and the Flora of Tropical East Africa [61]. The voucher collections were later verified at the East African (EA) herbarium in Kenya. All the voucher materials reported in this study were deposited at the EA (the collection details: localities, voucher numbers, elevation, and coordinates at sampling points are summarized in Table 1). The nomenclature of all the species 
TABLE 1: A summary of the collection details of the voucher materials cited by the herbalists at Mutomo hill plant sanctuary and its environs.

\begin{tabular}{|c|c|c|c|}
\hline Family and species name & Voucher number & Area of collection & Elevation and coordinates \\
\hline $\begin{array}{l}\text { Acanthaceae } \\
\text { Barleria eranthemoides } \\
\text { Amaranthaceae }\end{array}$ & Mutie MU0215 & Kitoo sublocation, Ndiini village & $836 \mathrm{~m}, 1^{\circ} 55^{\prime} 20.4^{\prime \prime} \mathrm{S}, 38^{\circ} 07^{\prime} 11.2^{\prime \prime} \mathrm{E}$ \\
\hline $\begin{array}{l}\text { Achyranthes aspera var. sicula } \\
\text { Anacardiaceae }\end{array}$ & Mutie MU0192 & Kawelu sublocation, Ngomeni village & $713 \mathrm{~m}, 1^{\circ} 49^{\prime} 49.8^{\prime \prime} \mathrm{S}, 38^{\circ} 12^{\prime} 23.0^{\prime \prime} \mathrm{E}$ \\
\hline $\begin{array}{l}\text { Lannea schweinfurthii } \\
\text { Apiaceae }\end{array}$ & Mutie MU0271 & Kibwea sublocation & $882 \mathrm{~m}, 1^{\circ} 52^{\prime} 56.1^{\prime \prime} \mathrm{S}, 38^{\circ} 15^{\prime} 14.6^{\prime \prime} \mathrm{E}$ \\
\hline $\begin{array}{l}\text { Steganotaenia araliacea } \\
\text { Apocynaceae }\end{array}$ & Mutie MU0243 & Mutomo hill plant sanctuary & $910 \mathrm{~m}, 1^{\circ} 49^{\prime} 49.8^{\prime \prime} \mathrm{S}, 38^{\circ} 12^{\prime} 23.0^{\prime \prime} \mathrm{E}$ \\
\hline Calotropis procera & Mutie MU0238 & Kibwea sublocation & $882 \mathrm{~m}, 1^{\circ} 52^{\prime} 56.1^{\prime \prime} \mathrm{S}, 38^{\circ} 15^{\prime} 14.6^{\prime \prime} \mathrm{E}$ \\
\hline $\begin{array}{l}\text { Edithcolea grandis } \\
\text { Asparagaceae }\end{array}$ & Mutie MU0216 & Kitoo sublocation, Ndiini village & $836 \mathrm{~m}, 1^{\circ} 55^{\prime} 20.4^{\prime \prime} \mathrm{S}, 38^{\circ} 07^{\prime} 11.2^{\prime \prime} \mathrm{E}$ \\
\hline $\begin{array}{l}\text { Sansevieria perrotii } \\
\text { Burseraceae }\end{array}$ & Mutie MU0063 & Mutomo hill plant sanctuary & $910 \mathrm{~m}, 1^{\circ} 49^{\prime} 49.8^{\prime \prime} \mathrm{S}, 38^{\circ} 12^{\prime} 23.0^{\prime \prime} \mathrm{E}$ \\
\hline Commiphora baluensis & Mutie MU0190 & Kawelu sublocation & $713 \mathrm{~m}, 1^{\circ} 49^{\prime} 49.8^{\prime \prime} \mathrm{S}, 38^{\circ} 12^{\prime} 23.0^{\prime \prime} \mathrm{E}$ \\
\hline Commiphora edulis & Mutie MU0193 & Kawelu sublocation & $713 \mathrm{~m}, 1^{\circ} 49^{\prime} 49.8^{\prime \prime} \mathrm{S}, 38^{\circ} 12^{\prime} 23.0^{\prime \prime} \mathrm{E}$ \\
\hline $\begin{array}{l}\text { Commiphora habessinica } \\
\text { Capparaceae }\end{array}$ & Mutie MU0174 & Kitoo sublocation & $836 \mathrm{~m}, 1^{\circ} 54^{\prime} 46.1^{\prime \prime} \mathrm{S}, 38^{\circ} 11^{\prime} 00.9^{\prime \prime} \mathrm{E}$ \\
\hline Boscia coriacea & Mutie MU0222 & Kawelu sublocation & $705 \mathrm{~m}, 1^{\circ} 47^{\prime} 12.3^{\prime \prime} \mathrm{S}, 38^{\circ} 14^{\prime} 19.5^{\prime \prime} \mathrm{E}$ \\
\hline $\begin{array}{l}\text { Maerua endlichii } \\
\text { Combretaceae }\end{array}$ & Mutie MU0201 & Kibwea sublocation & $705 \mathrm{~m}, 1^{\circ} 47^{\prime} 12.3^{\prime \prime} \mathrm{S}, 38^{\circ} 14^{\prime} 19.5^{\prime \prime} \mathrm{E}$ \\
\hline Combretum hereroense & Mutie MU0203 & Kibwea sublocation & $676 \mathrm{~m}, 1^{\circ} 44^{\prime} 09.9^{\prime \prime} \mathrm{S}, 38^{\circ} 13^{\prime} 36.0^{\prime \prime} \mathrm{E}$ \\
\hline Terminalia brownii & Mutie MU0226 & Kibwea sublocation & $882 \mathrm{~m}, 1^{\circ} 52^{\prime} 56.1^{\prime \prime} \mathrm{S}, 38^{\circ} 15^{\prime} 14.6^{\prime \prime} \mathrm{E}$ \\
\hline $\begin{array}{l}\text { Terminalia prunioides } \\
\text { Compositae }\end{array}$ & Mutie MU0091 & Mutomo hill plant sanctuary & $910 \mathrm{~m}, 1^{\circ} 49^{\prime} 49.8^{\prime \prime} \mathrm{S}, 38^{\circ} 12^{\prime} 23.0^{\prime \prime} \mathrm{E}$ \\
\hline Aspilia pluriseta & Mutie MU0225 & Kibwea sublocation & $882 \mathrm{~m}, 1^{\circ} 52^{\prime} 56.1^{\prime \prime} \mathrm{S}, 38^{\circ} 15^{\prime} 14.6^{\prime \prime} \mathrm{E}$ \\
\hline Kleinia squarrosa & Mutie MU0199 & Kawelu sublocation & $713 \mathrm{~m}, 1^{\circ} 49^{\prime} 49.8^{\prime \prime} \mathrm{S}, 38^{\circ} 12^{\prime} 23.0^{\prime \prime} \mathrm{E}$ \\
\hline Launaea cornuta & Mutie MU0209 & Kitoo sublocation & $836 \mathrm{~m}, 1^{\circ} 54^{\prime} 46.1^{\prime \prime} \mathrm{S}, 38^{\circ} 11^{\prime} 00.9^{\prime \prime} \mathrm{E}$ \\
\hline Sphaeranthus kirkii var. cyathuloides & Mutie MU0219 & Kawelu sublocation & $853 \mathrm{~m}, 1^{\circ} 51^{\prime} 03.3^{\prime \prime} \mathrm{S}, 38^{\circ} 09^{\prime} 57.8^{\prime \prime} \mathrm{E}$ \\
\hline Tridax procumbens & Mutie MU0227 & Mwala sublocation & $868 \mathrm{~m}, 1^{\circ} 52^{\prime} 56.2^{\prime \prime} \mathrm{S}, 38^{\circ} 15^{\prime} 14.2^{\prime \prime} \mathrm{E}$ \\
\hline $\begin{array}{l}\text { Cucurbitaceae } \\
\text { Kedrostis pseudogijef } \\
\text { Euphorbiaceae }\end{array}$ & Mutie MU0212 & Kitoo sublocation, Ndiini village & $836 \mathrm{~m}, 1^{\circ} 55^{\prime} 20.4^{\prime \prime} \mathrm{S}, 38^{\circ} 07^{\prime} 11.2^{\prime \prime} \mathrm{E}$ \\
\hline Croton dichogamus & Mutie MU0245 & Kitoo sublocation, Ndiini village & $836 \mathrm{~m}, 1^{\circ} 55^{\prime \prime} 20.4^{\prime} \mathrm{S}, 38^{\circ} 07^{\prime \prime} 11.2^{\prime} \mathrm{E}$ \\
\hline Croton megalocarpus & Mutie MU0228 & Mwala sublocation & $868 \mathrm{~m}, 1^{\circ} 52^{\prime} 56.2^{\prime \prime} \mathrm{S}, 38^{\circ} 15^{\prime} 14.2^{\prime \prime} \mathrm{E}$ \\
\hline Euphorbia crotonoides & Mutie MU0009 & Mutomo hill plant sanctuary & $910 \mathrm{~m}, 1^{\circ} 49^{\prime} 49.8^{\prime \prime} \mathrm{S}, 38^{\circ} 12^{\prime} 23.0^{\prime \prime} \mathrm{E}$ \\
\hline Euphorbia scheffleri & Mutie MU0038 & Mutomo hill plant sanctuary & $910 \mathrm{~m}, 1^{\circ} 49^{\prime} 49.8^{\prime \prime} \mathrm{S}, 38^{\circ} 12^{\prime} 23.0^{\prime \prime} \mathrm{E}$ \\
\hline Euphorbia uhligiana & Mutie MU0066 & Mutomo hill plant sanctuary & $910 \mathrm{~m}, 1^{\circ} 49^{\prime} 49.8^{\prime \prime} \mathrm{S}, 38^{\circ} 12^{\prime} 23.0^{\prime \prime} \mathrm{E}$ \\
\hline Ricinus communis & Mutie MU0205 & Kitoo sublocation & $836 \mathrm{~m}, 1^{\circ} 54^{\prime} 46.1^{\prime \prime} \mathrm{S}, 38^{\circ} 11^{\prime} 00.9^{\prime \prime} \mathrm{E}$ \\
\hline Lamiaceae & & & \\
\hline Endostemon tereticaulis & Mutie MU0231 & Kandae sublocation & $868 \mathrm{~m}, 1^{\circ} 52^{\prime} 56.2^{\prime \prime} \mathrm{S}, 38^{\circ} 15^{\prime} 14.2^{\prime \prime} \mathrm{E}$ \\
\hline Hoslundia opposita & Mutie MU0244 & Mutomo hill plant sanctuary & $910 \mathrm{~m}, 1^{\circ} 49^{\prime} 49.8^{\prime \prime} \mathrm{S}, 38^{\circ} 12^{\prime} 23.0^{\prime \prime} \mathrm{E}$ \\
\hline Plectranthus lasianthus & Mutie MU0217 & Kitoo sublocation, Ndiini village & $836 \mathrm{~m}, 1^{\circ} 55^{\prime} 20.4^{\prime \prime} \mathrm{S}, 38^{\circ} 07^{\prime} 11.2^{\prime \prime} \mathrm{E}$ \\
\hline Plectranthus otostegioides & Mutie MU0235 & Kibwea sublocation & $882 \mathrm{~m}, 1^{\circ} 52^{\prime} 56.1^{\prime \prime} \mathrm{S}, 38^{\circ} 15^{\prime} 14.6^{\prime \prime} \mathrm{E}$ \\
\hline Pycnostachys umbrosa & Mutie MU0213 & Kitoo sublocation, Ndiini village & $836 \mathrm{~m}, 1^{\circ} 55^{\prime} 20.4^{\prime \prime} \mathrm{S}, 38^{\circ} 07^{\prime} 11.2^{\prime \prime} \mathrm{E}$ \\
\hline Volkameria eriophylla & Mutie MU0291 & Mwala sublocation & $868 \mathrm{~m}, 1^{\circ} 52^{\prime} 56.2^{\prime \prime} \mathrm{S}, 38^{\circ} 15^{\prime} 14.2^{\prime \prime} \mathrm{E}$ \\
\hline Leguminosae & & & \\
\hline Acacia brevispica & Mutie MU0031 & Mutomo hill plant sanctuary & $910 \mathrm{~m}, 1^{\circ} 49^{\prime} 49.8^{\prime \prime} \mathrm{S}, 38^{\circ} 12^{\prime} 23.0^{\prime \prime} \mathrm{E}$ \\
\hline Acacia mellifera & Mutie MU0246 & Mutomo hill plant sanctuary & $910 \mathrm{~m}, 1^{\circ} 49^{\prime} 49.8^{\prime \prime} \mathrm{S}, 38^{\circ} 12^{\prime} 23.0^{\prime \prime} \mathrm{E}$ \\
\hline Acacia nilotica & Mutie MU0224 & Kibwea sublocation & $882 \mathrm{~m}, 1^{\circ} 52^{\prime} 56.1^{\prime \prime} \mathrm{S}, 38^{\circ} 15^{\prime} 14.6^{\prime \prime} \mathrm{E}$ \\
\hline Acacia tortilis & Mutie MU0198 & Kawelu sublocation & $713 \mathrm{~m}, 1^{\circ} 49^{\prime} 49.8^{\prime \prime} \mathrm{S}, 38^{\circ} 12^{\prime} 23.0^{\prime \prime} \mathrm{E}$ \\
\hline Albizia anthelmintica & Mutie MU0194 & Kawelu sublocation & $713 \mathrm{~m}, 1^{\circ} 49^{\prime} 49.8^{\prime \prime} \mathrm{S}, 38^{\circ} 12^{\prime} 23.0^{\prime \prime} \mathrm{E}$ \\
\hline Cassia abbreviata & Mutie MU0221 & Kawelu sublocation & $853 \mathrm{~m}, 1^{\circ} 51^{\prime} 03.3^{\prime \prime} \mathrm{S}, 38^{\circ} 09^{\prime} 57.8^{\prime \prime} \mathrm{E}$ \\
\hline Delonix elata & Mutie MU0233 & Kibwea sublocation & $868 \mathrm{~m}, 1^{\circ} 52^{\prime} 56.1^{\prime \prime} \mathrm{S}, 38^{\circ} 15^{\prime} 14.6^{\prime \prime} \mathrm{E}$ \\
\hline Dichrostachys cinerea & Mutie MU0232 & Kandae sublocation & $868 \mathrm{~m}, 1^{\circ} 52^{\prime} 56.2^{\prime \prime} \mathrm{S}, 38^{\circ} 15^{\prime} 14.2^{\prime \prime} \mathrm{E}$ \\
\hline Entada leptostachya & Mutie MU0229 & Mwala sublocation & $868 \mathrm{~m}, 1^{\circ} 52^{\prime} 56.2^{\prime \prime} \mathrm{S}, 38^{\circ} 15^{\prime} 14.2^{\prime \prime} \mathrm{E}$ \\
\hline Indigofera lupatana & Mutie MU0053 & Mutomo hill plant sanctuary & $910 \mathrm{~m}, 1^{\circ} 49^{\prime} 49.8^{\prime \prime} \mathrm{S}, 38^{\circ} 12^{\prime} 23.0^{\prime \prime} \mathrm{E}$ \\
\hline Senna occidentalis & Mutie MU0237 & Kibwea sublocation & $882 \mathrm{~m}, 1^{\circ} 52^{\prime} 56.1^{\prime \prime} \mathrm{S}, 38^{\circ} 15^{\prime} 14.6^{\prime \prime} \mathrm{E}$ \\
\hline Tamarindus indica & Mutie MU0208 & Kitoo sublocation & $836 \mathrm{~m}, 1^{\circ} 54^{\prime} 46.1^{\prime \prime} \mathrm{S}, 38^{\circ} 11^{\prime} 00.9^{\prime \prime} \mathrm{E}$ \\
\hline Tephrosia villosa & Mutie MU0054 & Mutomo hill plant sanctuary & $910 \mathrm{~m}, 1^{\circ} 49^{\prime} 49.8^{\prime \prime} \mathrm{S}, 38^{\circ} 12^{\prime} 23.0^{\prime \prime} \mathrm{E}$ \\
\hline
\end{tabular}


TABLE 1: Continued.

\begin{tabular}{|c|c|c|c|}
\hline Family and species name & Voucher number & Area of collection & Elevation and coordinates \\
\hline $\begin{array}{l}\text { Loganiaceae } \\
\text { Strychnos henningsii } \\
\text { Malvaceae }\end{array}$ & Mutie MU0200 & Mwala sublocation & $868 \mathrm{~m}, 1^{\circ} 52^{\prime} 56.2^{\prime \prime} \mathrm{S}, 38^{\circ} 15^{\prime} 14.2^{\prime \prime} \mathrm{E}$ \\
\hline Grewia tembensis & Mutie MU0242 & Mutomo hill plant sanctuary & $910 \mathrm{~m}, 1^{\circ} 49^{\prime} 49.8^{\prime \prime} \mathrm{S}, 38^{\circ} 12^{\prime} 23.0^{\prime \prime} \mathrm{E}$ \\
\hline Grewia tephrodermis & Mutie MU0220 & Kawelu sublocation & $853 \mathrm{~m}, 1^{\circ} 51^{\prime} 03.3^{\prime \prime} \mathrm{S}, 38^{\circ} 09^{\prime} 57.8^{\prime \prime} \mathrm{E}$ \\
\hline Grewia villosa & Mutie MU0206 & Kitoo sublocation & $836 \mathrm{~m}, 1^{\circ} 54^{\prime} 46.1^{\prime \prime} \mathrm{S}, 38^{\circ} 11^{\prime} 00.9^{\prime \prime} \mathrm{E}$ \\
\hline $\begin{array}{l}\text { Sterculia africana } \\
\text { Meliaceae }\end{array}$ & Mutie MU0211 & Kitoo sublocation & $836 \mathrm{~m}, 1^{\circ} 54^{\prime} 46.1^{\prime \prime} \mathrm{S}, 38^{\circ} 11^{\prime} 00.9^{\prime \prime} \mathrm{E}$ \\
\hline $\begin{array}{l}\text { Melia volkensii } \\
\text { Menispermaceae }\end{array}$ & Mutie MU0223 & Kibwea sublocation & $882 \mathrm{~m}, 1^{\circ} 52^{\prime} 56.1^{\prime \prime} \mathrm{S}, 38^{\circ} 15^{\prime} 14.6^{\prime \prime} \mathrm{E}$ \\
\hline Chasmanthera dependens & Mutie MU0039 & Mutomo hill plant sanctuary & $910 \mathrm{~m}, 1^{\circ} 49^{\prime} 49.8^{\prime \prime} \mathrm{S}, 38^{\circ} 12^{\prime} 23.0^{\prime \prime} \mathrm{E}$ \\
\hline $\begin{array}{l}\text { Cissampelos pareira } \\
\text { Moraceae }\end{array}$ & Mutie MU0005 & Mutomo hill plant sanctuary & $910 \mathrm{~m}, 1^{\circ} 49^{\prime} 49.8^{\prime \prime} \mathrm{S}, 38^{\circ} 12^{\prime} 23.0^{\prime \prime} \mathrm{E}$ \\
\hline $\begin{array}{l}\text { Ficus sycomorus } \\
\text { Moringaceae }\end{array}$ & Mutie MU0202 & Kibwea sublocation, Masaa river & $676 \mathrm{~m}, 1^{\circ} 44^{\prime} 09.9^{\prime \prime} \mathrm{S}, 38^{\circ} 13^{\prime} 36.0^{\prime \prime} \mathrm{E}$ \\
\hline $\begin{array}{l}\text { Moringa borziana } \\
\text { Phyllanthaceae }\end{array}$ & Mutie MU0236 & Kibwea sublocation & $882 \mathrm{~m}, 1^{\circ} 52^{\prime} 56.1^{\prime \prime} \mathrm{S}, 38^{\circ} 15^{\prime} 14.6^{\prime \prime} \mathrm{E}$ \\
\hline $\begin{array}{l}\text { Bridelia taitensis } \\
\text { Plumbaginaceae }\end{array}$ & Mutie MU0239 & Mutomo hill plant sanctuary & $882 \mathrm{~m}, 1^{\circ} 52^{\prime} 56.1^{\prime \prime} \mathrm{S}, 38^{\circ} 15^{\prime} 14.6^{\prime \prime} \mathrm{E}$ \\
\hline $\begin{array}{l}\text { Plumbago zeylanica } \\
\text { Rubiaceae }\end{array}$ & Mutie MU0189 & Kawelu sublocation, Ngomeni village & $713 \mathrm{~m}, 1^{\circ} 49^{\prime} 49.8^{\prime \prime} \mathrm{S}, 38^{\circ} 12^{\prime} 23.0^{\prime \prime} \mathrm{E}$ \\
\hline Hymenodictyon parvifolium & Mutie MU0050 & Mutomo hill plant sanctuary & $910 \mathrm{~m}, 1^{\circ} 49^{\prime} 49.8^{\prime \prime} \mathrm{S}, 38^{\circ} 12^{\prime} 23.0^{\prime \prime} \mathrm{E}$ \\
\hline $\begin{array}{l}\text { Tennantia sennii } \\
\text { Rutaceae }\end{array}$ & Mutie MU0027 & Kitoo sublocation & $836 \mathrm{~m}, 1^{\circ} 54^{\prime} 46.1^{\prime \prime} \mathrm{S}, 38^{\circ} 11^{\prime} 00.9^{\prime \prime} \mathrm{E}$ \\
\hline Vepris simplicifolia & Mutie MU0234 & Mutomo hill plant sanctuary & $882 \mathrm{~m}, 1^{\circ} 52^{\prime} 56.1^{\prime \prime} \mathrm{S}, 38^{\circ} 15^{\prime} 14.6^{\prime \prime} \mathrm{E}$ \\
\hline $\begin{array}{l}\text { Zanthoxylum chalybeum } \\
\text { Solanaceae }\end{array}$ & Mutie MU0317 & Kandae sublocation & $868 \mathrm{~m}, 1^{\circ} 52^{\prime} 56.2^{\prime \prime} \mathrm{S}, 38^{\circ} 15^{\prime} 14.2^{\prime \prime} \mathrm{E}$ \\
\hline Solanum campylacanthum & Mutie MU0218 & Kitoo sublocation, Ndiini village & $836 \mathrm{~m}, 1^{\circ} 55^{\prime} 20.4^{\prime \prime} \mathrm{S}, 38^{\circ} 07^{\prime} 11.2^{\prime \prime} \mathrm{E}$ \\
\hline $\begin{array}{l}\text { Solanum tettense } \\
\text { Vitaceae }\end{array}$ & Mutie MU0214 & Kitoo sublocation, Ndiini village & $836 \mathrm{~m}, 1^{\circ} 55^{\prime} 20.4^{\prime \prime} \mathrm{S}, 38^{\circ} 07^{\prime} 11.2^{\prime \prime} \mathrm{E}$ \\
\hline Cissus aphyllantha & Mutie MU0247 & Mutomo hill plant sanctuary & $910 \mathrm{~m}, 1^{\circ} 49^{\prime} 49.8^{\prime \prime} \mathrm{S}, 38^{\circ} 12^{\prime} 23.0^{\prime \prime} \mathrm{E}$ \\
\hline Cissus quadrangularis & Mutie MU0054 & Mutomo hill plant sanctuary & $910 \mathrm{~m}, 1^{\circ} 49^{\prime} 49.8^{\prime \prime} \mathrm{S}, 38^{\circ} 12^{\prime} 23.0^{\prime \prime} \mathrm{E}$ \\
\hline $\begin{array}{l}\text { Cissus rotundifolia } \\
\text { Xanthorrhoeaceae }\end{array}$ & Mutie MU0128 & Mutomo hill plant sanctuary & $910 \mathrm{~m}, 1^{\circ} 49^{\prime} 49.8^{\prime \prime} \mathrm{S}, 38^{\circ} 12^{\prime} 23.0^{\prime \prime} \mathrm{E}$ \\
\hline $\begin{array}{l}\text { Aloe secundiflora } \\
\text { Zygophyllaceae }\end{array}$ & Mutie MU0191 & Kawelu sublocation, Ngomeni village & $713 \mathrm{~m}, 1^{\circ} 49^{\prime} 49.8^{\prime \prime} \mathrm{S}, 38^{\circ} 12^{\prime} 23.0^{\prime \prime} \mathrm{E}$ \\
\hline Balanites aegyptiaca & Mutie MU0210 & Kitoo sublocation & $836 \mathrm{~m}, 1^{\circ} 54^{\prime} 46.1^{\prime \prime} \mathrm{S}, 38^{\circ} 11^{\prime} 00.9^{\prime \prime} \mathrm{E}$ \\
\hline
\end{tabular}

names was further verified using The Plant List (http://www. theplantlist.org/).

The plant parts used for herbal medicines were classified according to Cook [62] while the plant growth habits were classified based on the monographs of Kenyan flora [59, 60]. The health conditions reported in the study area were classified according to Cook [62], where all the diseases reported by the informants belong to level one category of "medicines" while each disease cited by the informants belongs to a certain "level two category" within "level one category." Where the disorders could not be matched directly to level two categories, the body parts affected by the disorders were matched with their level two respective categories until all the ailments reported were categorized. The data were entered into an excel spreadsheet and analyzed to determine plant growth habit proportions, proportions of plant parts used, diseases treated, and the priority plant species based on Relative Frequency of Citation values (RFC). The RFC for each species was quantitatively calculated using the formula $\mathrm{RFC}=(\mathrm{FC} / N)(0<\mathrm{RFC}<1)[63]$, where the $\mathrm{FC}$ is the Frequency Citation, while $N$ is the number of respondents participating in a particular study (here, $N=48$ ). The RFC determines the consensus between the informants on the use of a reported plant species in a given area which in turn gives its local importance. The RFC values range from 0 to 1 , where $\mathrm{RFC}=0$ indicates that no informant mentioned the particular plant species while $\mathrm{RFC}=1$ indicates that the plant species was cited by all informants in a particular study.

\section{Results}

3.1. Sociodemographic Data. A total of 48 local herbalists composed of 32 males and 16 females, aged between 32 and 96 years, with an average age of 68.25 years were interviewed. One herbalist was old (96 years) and collected the medicinal plants near his homestead. Two of the female herbalists sold the medicinal plants at Mutomo market, while all the other herbalists were farmers and served their customers or patients when consulted or visited. A majority (27\%) of the herbalists were aged between 71 and 80 years and between 61 and 70 years $(25 \%)$ while a number of them $(18.75 \%)$ were 
over 80 years old. Only $2.08 \%$ of the herbalists were below 40 years old. In terms of education, majority of the herbalists (77.08\%) had no formal education, $20.83 \%$ had at least attended primary school education although none of them had completed, while only $2.08 \%$ of the herbalists had completed secondary school training (Table 2).

3.2. Medicinal Flora. Sixty-eight (68) plant species distributed in 28 families and 54 genera (Table 3 ) were reported to be used in the management of various human health conditions. Leguminosae comprised the majority of the species (13), followed by Euphorbiaceae and Lamiaceae, each with six species. A majority of the plant families comprised one species (Figure 2).

3.3. Growth Habit of the Medicinal Plants. Shrubs (37\%) and trees (34\%) were cited by the informants to be frequently collected for herbal medicine while herbs (18\%), climbers (6\%), and lianas (4\%) were least cited (Figure 3).

3.4. Plant Parts Collected for Herbal Medicine. Roots and barks (each with 19 species) were reported to be the common plant parts collected for herbal medicine, followed by leaves (16 species), exudates (11 species), aerial parts (9 species), whole plants (4 species), fruits (4 species), stems (2 species) and inflorescence (1 species).

3.5. Frequently Collected Medicinal Plants. The RFC for each plant species was calculated. A summary of the RFC values of all medicinal plants reported from Mutomo hill plant sanctuary and its environs are outlined (Table 3). Plant species with five or more citations $(\mathrm{RFC} \geq 0.10)$ were considered as the priority plant species. In total, 24 plant species were frequently cited by the respondents. Cassia abbreviata $(\mathrm{RFC}=0.63)$, Acacia nilotica $(\mathrm{RFC}=0.54)$, Strychnos henningsii $(\mathrm{RFC}=0.46)$, and Aloe secundiflora $(\mathrm{RFC}=0.31)$ had the highest RFC values (Figure 4).

3.6. Health Conditions Reported. In total, 13 disease categories including ethnoveterinary diseases were reported during the study. Infectious diseases and infestations were found to be treated with majority of the plant species (33) followed by digestive system disorders (24 plant species) (Table 4). These two disease categories are discussed in detail due to their perceived important role in the health of the people in the study area.

\section{Discussion}

4.1. Sociodemographic Data. All the herbalists who participated in the study were over 30 years old, mostly dwelling in the rural areas. People living in the rural areas are reported to acquire more ethnobotanical knowledge probably due to the availability of plants in their surroundings [75]. A large percentage of the herbalists had no formal education, a proportion that was below the national average level of adult literacy in Kenya [76]. The low level of formal education in
TABle 2: Demographic information of the herbalists.

\begin{tabular}{lc}
\hline Parameter & Percentage (\%) composition \\
\hline Demographic data & \\
Male & 66.67 \\
Female & 33.33 \\
Age group in years & \\
$31-40$ & 2.08 \\
$41-50$ & 12.5 \\
$51-60$ & 14.58 \\
$61-70$ & 25 \\
$71-80$ & 27 \\
$>80$ & 18.75 \\
Level of education & \\
Secondary school education & 2.08 \\
Primary school education & 20.83 \\
No formal education & 77.08 \\
\hline
\end{tabular}

herbal practitioners has also been reported in other regions of Kenya [67, 77]. This contradicts a previous study in Kitui county where most of the respondents had acquired formal education up to primary school level [34]. According to a report by the county government of Kitui, people over 65 years old are considered aged and not economically productive [54]. In this study, however, the aged people were found to be actively practicing traditional medicine which in some instances was a source of income since some of them sold the herbal products in the market. Elderly people practicing traditional medicine has been reported elsewhere in Kenya [77]. It is also argued that the level of ethnobotanical knowledge may increase as people advance in age probably due to increased responsibilities [75] which partly explains the high number of aged herbalists. Generally, the population of females is higher than that of males in Kitui county [54], yet most of the herbalists in the study were males. This agrees with Kaingu et al. [77] who reported males to comprise most of the herbalists in a previous study, although this is contradicted by a recent study in Kitui county [34] where women were reported to comprise most of the respondents. Despite such variations, there may be no difference in the level of ethnobotanical knowledge between the two genders [75].

Most of the herbalists preferred collecting medicinal plants on their own, which in some cases involved travelling for hours, unless a plant species could be found in their vicinity or was an obvious tree, where they could ask for assistance. The herbalists who stored herbal materials for future use also kept it a secret and normally stored them mixed together or ground into a powder to make utilization or identification by an unfamiliar person difficult. In addition, most of the herbalists chose to be interviewed in the absence of other people including some of their family members except their spouses and one or two confidants. This is likely to contribute to the degradation of traditional knowledge in young generations since the chances of acquiring it are controlled by those who possess it. Although Kisangau et al. [34] found that most of the respondents had acquired traditional knowledge through apprenticeship from family members, Muthee et al. [67] argues that the poor traditional knowledge in young generations could be an 
TABLE 3: An account of the medicinal plants reported in Mutomo hill plant sanctuary and its environs. The relevant reported medicinal uses of the plant species or literature reporting other medicinal applications of the plant species have been indicated where possible.

\begin{tabular}{|c|c|c|c|c|c|c|c|}
\hline $\begin{array}{l}\text { Family and species } \\
\text { name }\end{array}$ & Local name & Habit & RFC & $\begin{array}{c}\text { Parts } \\
\text { collected }\end{array}$ & $\begin{array}{l}\text { Drug preparation and } \\
\text { administration }\end{array}$ & Disease treated & $\begin{array}{c}\text { Relevant reported disease } \\
\text { treated or use }\end{array}$ \\
\hline $\begin{array}{l}\text { Acanthaceae } \\
\text { Barleria } \\
\text { eranthemoides } \\
\text { R.Br. Ex } \\
\text { C.B.Clarke } \\
\text { Amaranthaceae }\end{array}$ & Thangila & Shrub & 0.06 & Leaf, root & $\begin{array}{l}\text { A poultice is applied } \\
\text { topically }\end{array}$ & $\begin{array}{l}\text { Foreign objects } \\
\text { pierced into the } \\
\text { skin and boils }\end{array}$ & References $[13,64]$ \\
\hline $\begin{array}{l}\text { Achyranthes } \\
\text { aspera var. sicula } \\
\text { L. }\end{array}$ & Musekele & Herb & 0.02 & Whole plant & $\begin{array}{l}\text { Burnt to charcoal and } \\
\text { ground into a powder } \\
\text { which is taken in hot } \\
\text { drinks. The powder is } \\
\text { alternatively rubbed on } \\
\text { a bleeding part of the } \\
\text { body that is cut with a } \\
\text { razor adjacent to the } \\
\text { kidney }\end{array}$ & Kidney pains & $\begin{array}{l}\text { Urinary tract problems } \\
\qquad[41]\end{array}$ \\
\hline $\begin{array}{l}\text { Anacardiaceae } \\
\text { Lannea } \\
\text { schweinfurthii } \\
\text { Engl. } \\
\text { Apiaceae }\end{array}$ & Kyuasi & Tree & 0.02 & Bark & An infusion is drunk & Gonorrhea & $\begin{array}{c}\text { Gonorrhea, venereal } \\
\text { diseases, and gynecological } \\
\text { problems }[1,44,64]\end{array}$ \\
\hline $\begin{array}{l}\text { Steganotaenia } \\
\text { araliacea Hochst. }\end{array}$ & Kivwavui & Tree & 0.04 & $\begin{array}{l}\text { Exudate, } \\
\text { aerial parts }\end{array}$ & $\begin{array}{l}\text { An exudate is dropped } \\
\text { into the eyes in case of } \\
\text { sensitiveness or } \\
\text { itching. An infusion } \\
\text { from aerial parts is } \\
\text { steam bathed for } \\
\text { edema }\end{array}$ & $\begin{array}{l}\text { Itching eyes, } \\
\text { sensitive eyes, } \\
\text { edema }\end{array}$ & $\begin{array}{c}\text { Edema, partial blindness, } \\
\text { and body swellings } \\
\text { resulting from allergy } \\
{[1,41,64]}\end{array}$ \\
\hline \multicolumn{8}{|l|}{ Apocynaceae } \\
\hline $\begin{array}{l}\text { Calotropis procera } \\
\text { (Aiton) Dryand. }\end{array}$ & Ilumbu & Shrub & 0.04 & Exudate & Applied topically & $\begin{array}{l}\text { Foreign objects } \\
\text { pierced into the } \\
\text { body }\end{array}$ & $\begin{array}{l}\text { Removing splinters } \\
\text { pierced into the body [64] }\end{array}$ \\
\hline $\begin{array}{l}\text { Edithcolea grandis } \\
\text { N.E.Br. } \\
\text { Asparagaceae }\end{array}$ & Mutulya-ndu & Herb & 0.02 & Exudate & $\begin{array}{l}\text { Applied topically on } \\
\text { infected skin }\end{array}$ & Ringworms & Reference [64] \\
\hline $\begin{array}{l}\text { Sansevieria } \\
\text { perrotti Warb. }\end{array}$ & Kiwa kya ndui & Herb & 0.02 & Exudate & $\begin{array}{l}\text { The leaf is heated in } \\
\text { hot ash and the } \\
\text { exudate squeezed into } \\
\text { the ear. The treatment } \\
\text { is initiated when the } \\
\text { ear starts to ooze pus }\end{array}$ & Earache & $\begin{array}{l}\text { Cuts and body aches } \\
\qquad[1,65]\end{array}$ \\
\hline \multicolumn{8}{|l|}{ Burseraceae } \\
\hline $\begin{array}{l}\text { Commiphora } \\
\text { baluensis Engl. }\end{array}$ & Itula & Tree & 0.15 & Bark & $\begin{array}{l}\text { An infusion is drunk. } \\
\text { Alternatively, the bark } \\
\text { is dried and ground } \\
\text { into a powder which is } \\
\text { infused in hot drinks }\end{array}$ & $\begin{array}{l}\text { Diarrhea, } \\
\text { swollen } \\
\text { diaphragm }\end{array}$ & Peptic ulcers [64] \\
\hline $\begin{array}{l}\text { Commiphora } \\
\text { edulis (Klotzsch) } \\
\text { Engl. }\end{array}$ & Kyoa kika & Tree & 0.04 & Bark & An infusion is drunk & $\begin{array}{l}\text { Tapeworms, } \\
\text { cough, chest } \\
\text { pains }\end{array}$ & $\begin{array}{l}\text { Diarrhea, dysentery, and } \\
\text { indigestion }[1,44]\end{array}$ \\
\hline $\begin{array}{l}\text { Commiphora } \\
\text { habessinica } \\
\text { (O.Berg) Engl. } \\
\text { Capparaceae }\end{array}$ & Mutungati & Tree & 0.06 & Exudate & Applied topically & Septic wounds & Old wounds [64] \\
\hline $\begin{array}{l}\text { Boscia coriacea } \\
\text { Graells }\end{array}$ & Musivu & Shrub & 0.06 & Leaf & An infusion is drunk & Diarrhea & $\begin{array}{c}\text { Stomach-ache } \\
{[1,29,66]}\end{array}$ \\
\hline
\end{tabular}


TABle 3: Continued.

\begin{tabular}{|c|c|c|c|c|c|c|c|}
\hline $\begin{array}{l}\text { Family and species } \\
\text { name }\end{array}$ & Local name & Habit & $\mathrm{RFC}$ & $\begin{array}{c}\text { Parts } \\
\text { collected }\end{array}$ & $\begin{array}{l}\text { Drug preparation and } \\
\text { administration }\end{array}$ & Disease treated & $\begin{array}{l}\text { Relevant reported disease } \\
\text { treated or use }\end{array}$ \\
\hline $\begin{array}{l}\text { Maerua endlichii } \\
\text { Gilg and Bened. }\end{array}$ & Muthitu & Shrub & 0.02 & Stem & $\begin{array}{l}\text { Burnt into charcoal, } \\
\text { ground into a powder, } \\
\text { and infused in hot } \\
\text { drinks }\end{array}$ & $\begin{array}{c}\text { Swollen } \\
\text { diaphragm }\end{array}$ & Reference [29] \\
\hline \multicolumn{8}{|l|}{ Combretaceae } \\
\hline $\begin{array}{l}\text { Combretum } \\
\text { hereroense Schinz }\end{array}$ & Mukokola & Shrub & 0.06 & Leaf & $\begin{array}{l}\text { Chewed and the } \\
\text { extract swallowed }\end{array}$ & $\begin{array}{l}\text { Tuberculosis, } \\
\text { cough }\end{array}$ & Chest pains [44] \\
\hline $\begin{array}{l}\text { Terminalia } \\
\text { brownii Fresen. }\end{array}$ & Kiuku & Tree & 0.29 & Bark & $\begin{array}{l}\text { Bark from the stems or } \\
\text { roots is chewed and the } \\
\text { extracts swallowed for } \\
\text { cough. A warm } \\
\text { infusion is bathed } \\
\text { for yellow fever and } \\
\text { drunk against diarrhea }\end{array}$ & $\begin{array}{l}\text { Cough, yellow } \\
\text { fever, and } \\
\text { diarrhea }\end{array}$ & $\begin{array}{l}\text { Yellow fever, jaundice, } \\
\text { stomach-ache, } \\
\text { gastrointestinal } \\
\text { complications, } \\
\text { and cough } \\
{[1,29,34,36,66]}\end{array}$ \\
\hline $\begin{array}{l}\text { Terminalia } \\
\text { prunioides } \\
\text { M.A.Lawson }\end{array}$ & Kitoo & Tree & 0.02 & Bark & A decoction is drunk & $\begin{array}{l}\text { Ringworms, } \\
\text { peptic ulcers, } \\
\text { kidney pains, } \\
\text { and } \\
\text { aphrodisiac in } \\
\text { men }\end{array}$ & Reference [60] \\
\hline $\begin{array}{l}\text { Compositae } \\
\text { Aspilia pluriseta } \\
\text { Schweinf. ex } \\
\text { Schweinf. }\end{array}$ & Muti & Shrub & 0.02 & Leaf & $\begin{array}{l}\text { A poultice is applied } \\
\text { topically }\end{array}$ & Fresh cuts & $\begin{array}{c}\text { Wounds and cuts } \\
{[1,34,64,66]}\end{array}$ \\
\hline $\begin{array}{l}\text { Kleinia squarrosa } \\
\text { Cufod. }\end{array}$ & $\begin{array}{l}\text { Mung'endya } \\
\text { Nthenge }\end{array}$ & Herb & 0.13 & Aerial parts & An infusion is bathed & $\begin{array}{l}\text { Malaria, } \\
\text { measles, } \\
\text { smallpox, and } \\
\text { edema }\end{array}$ & $\begin{array}{c}\text { Malaria and edema } \\
\quad[13,34,64]\end{array}$ \\
\hline $\begin{array}{l}\text { Launaea cornuta } \\
\text { (Hochst. ex Oliv. } \\
\text { and Hiern) } \\
\text { C.Jeffrey } \\
\text { Sphaeranthus }\end{array}$ & Uthunga & Herb & 0.08 & Aerial parts & An infusion is bathed & $\begin{array}{l}\text { Malaria, } \\
\text { smallpox, } \\
\text { edema }\end{array}$ & $\begin{array}{l}\text { Malaria, arthritis, and } \\
\text { measles }[1,34,64]\end{array}$ \\
\hline $\begin{array}{l}\text { kirkii var. } \\
\text { cyathuloides } \\
\text { (O.Hoffm.) } \\
\text { Beentje }\end{array}$ & Musonzoila & Herb & 0.10 & Aerial parts & An infusion is bathed & Malaria, edema & Headache [1] \\
\hline $\begin{array}{l}\text { Tridax procumbens } \\
\text { (L.) L. } \\
\text { Cucurbitaceae }\end{array}$ & Mumela & Herb & 0.04 & Leaf & $\begin{array}{c}\text { A poultice is applied } \\
\text { topically }\end{array}$ & $\begin{array}{l}\text { Fresh cuts, } \\
\text { wounds }\end{array}$ & Wounds [64] \\
\hline $\begin{array}{l}\text { Kedrostis } \\
\text { pseudogijef C. } \\
\text { Jeffrey }\end{array}$ & Mukauw'u & Climber & 0.04 & Leaf, exudate & $\begin{array}{c}\text { A leaf infusion is } \\
\text { bathed against measles. } \\
\text { An exudate applied on } \\
\text { fresh cuts }\end{array}$ & $\begin{array}{l}\text { Measles, fresh } \\
\text { cuts }\end{array}$ & Reference [64] \\
\hline \multicolumn{8}{|l|}{ Euphorbiaceae } \\
\hline $\begin{array}{l}\text { Croton } \\
\text { dichogamus Pax }\end{array}$ & Mwalula & Herb & 0.13 & Bark, leaf & $\begin{array}{l}\text { An infusion from the } \\
\text { bark is drunk for } \\
\text { malaria, back pains, } \\
\text { stomach-ache, edema, } \\
\text { and cough. An } \\
\text { infusion from the } \\
\text { leaves is bathed for } \\
\text { malaria. A root } \\
\text { decoction is drunk for } \\
\text { impotence and } \\
\text { infertility }\end{array}$ & $\begin{array}{l}\text { Malaria, back } \\
\text { pains, } \\
\text { stomach-ache, } \\
\text { edema, cough, } \\
\text { impotence, and } \\
\text { infertility }\end{array}$ & $\begin{array}{l}\text { Stomach-ache, chest } \\
\text { problems, fever, cough, } \\
\text { and as a tonic }[1,60,66]\end{array}$ \\
\hline
\end{tabular}


TABle 3: Continued.

\begin{tabular}{|c|c|c|c|c|c|c|c|}
\hline $\begin{array}{l}\text { Family and species } \\
\text { name }\end{array}$ & Local name & Habit & RFC & $\begin{array}{c}\text { Parts } \\
\text { collected }\end{array}$ & $\begin{array}{l}\text { Drug preparation and } \\
\text { administration }\end{array}$ & Disease treated & $\begin{array}{c}\text { Relevant reported disease } \\
\text { treated or use }\end{array}$ \\
\hline $\begin{array}{l}\text { Croton } \\
\text { megalocarpus } \\
\text { Hutch. }\end{array}$ & Muthulu & Tree & 0.19 & Bark, leaf & $\begin{array}{l}\text { An infusion from the } \\
\text { bark is drunk for } \\
\text { constipation and } \\
\text { stomach-ache. The } \\
\text { bark is alternatively } \\
\text { dried and ground into } \\
\text { a powder which is } \\
\text { infused in hot drinks. } \\
\text { A warm leaf infusion is } \\
\text { bathed against malaria } \\
\text { and colds }\end{array}$ & $\begin{array}{l}\text { Constipation, } \\
\text { stomach-ache, } \\
\text { malaria, colds }\end{array}$ & $\begin{array}{l}\text { Stomach-ache, diarrhea, } \\
\text { and malaria }[1,36,64]\end{array}$ \\
\hline $\begin{array}{l}\text { Euphorbia } \\
\text { crotonoides Boiss. }\end{array}$ & Kamweia & Herb & 0.02 & Exudate & Applied topically & Warts & Warts [1] \\
\hline $\begin{array}{l}\text { Euphorbia } \\
\text { scheffleri } \mathrm{Pax}\end{array}$ & Kilembwa & Shrub & 0.04 & Exudate & Applied topically & Fresh cuts & References $[1,13]$ \\
\hline $\begin{array}{l}\text { Euphorbia } \\
\text { uhligiana } \mathrm{Pax}\end{array}$ & Kyaa kinini & Herb & 0.02 & Whole plant & $\begin{array}{c}\text { Burnt to charcoal and } \\
\text { ground into a powder } \\
\text { which is infused in hot } \\
\text { drinks }\end{array}$ & Hypertension & References $[1,65]$ \\
\hline $\begin{array}{l}\text { Ricinus communis } \\
\text { L. }\end{array}$ & Mbaiki & Herb & 0.04 & Roots, seeds & $\begin{array}{l}\text { An infusion from the } \\
\text { root is drunk against } \\
\text { diarrhea. The anal } \\
\text { opening is exposed to } \\
\text { smoke from burning } \\
\text { seeds as a remedy for } \\
\text { pinworms }\end{array}$ & $\begin{array}{l}\text { Diarrhea, } \\
\text { pinworms }\end{array}$ & $\begin{array}{c}\text { Diarrhea and stomach- } \\
\text { ache, ruminal impaction } \\
\text { or constipation and as a } \\
\text { laxative } \\
{[1,34,41,64,66,67]}\end{array}$ \\
\hline \multicolumn{8}{|l|}{ Lamiaceae } \\
\hline $\begin{array}{l}\text { Endostemon } \\
\text { tereticaulis (Poir.) } \\
\text { M.R.Ashby }\end{array}$ & Mutaa & Herb & 0.10 & $\begin{array}{l}\text { Aerial parts, } \\
\text { roots }\end{array}$ & $\begin{array}{l}\text { An infusion from } \\
\text { aerial parts is bathed } \\
\text { and drunk against } \\
\text { malaria, edema, and } \\
\text { diarrhea. Powder from } \\
\text { dried roots is infused } \\
\text { in hot drinks as a } \\
\text { remedy against back } \\
\text { pains }\end{array}$ & $\begin{array}{l}\text { Malaria, edema } \\
\text { and diarrhea, } \\
\text { back pains }\end{array}$ & Reference [1] \\
\hline $\begin{array}{l}\text { Hoslundia } \\
\text { opposita Vahl }\end{array}$ & Musovi & Shrub & 0.02 & Leaf & $\begin{array}{c}\text { An infusion is steam } \\
\text { bathed }\end{array}$ & Edema & Edema [64] \\
\hline $\begin{array}{l}\text { Plectranthus } \\
\text { lasianthus (Gürke) } \\
\text { Vollesen }\end{array}$ & Kiyo & Herb & 0.02 & Whole plant & $\begin{array}{c}\text { An infusion is steam } \\
\text { bathed }\end{array}$ & $\begin{array}{l}\text { Kwashiorkor, } \\
\text { edema in } \\
\text { children }\end{array}$ & Reference [68] \\
\hline $\begin{array}{l}\text { Plectranthus } \\
\text { otostegioides } \\
\text { (Gürke) Ryding }\end{array}$ & Kyeu & Shrub & 0.02 & Whole plant & $\begin{array}{c}\text { An infusion is steam } \\
\text { bathed }\end{array}$ & $\begin{array}{l}\text { Kwashiorkor, } \\
\text { edema in } \\
\text { children }\end{array}$ & Reference [69] \\
\hline $\begin{array}{l}\text { Pycnostachys } \\
\text { umbrosa (Vatke) } \\
\text { Perkins }\end{array}$ & Muvou & Shrub & 0.02 & Root & An infusion is drunk & $\begin{array}{l}\text { Diarrhea, } \\
\text { stomach-ache }\end{array}$ & Emetic [60] \\
\hline $\begin{array}{l}\text { Volkameria } \\
\text { eriophylla (Gürke) } \\
\text { Mabb. and } \\
\text { Y.W.Yuan } \\
\text { Leguminosae }\end{array}$ & Muumba & Shrub & 0.15 & Leaf & $\begin{array}{c}\text { An infusion is drunk } \\
\text { and steam bathed } \\
\text { against malaria and } \\
\text { edema }\end{array}$ & Malaria, edema & Edema and malaria $[1,64]$ \\
\hline $\begin{array}{l}\text { Acacia brevispica } \\
\text { Harms }\end{array}$ & Mukuswi & Shrub & 0.02 & Aerial parts & $\begin{array}{c}\text { An infusion is steam } \\
\text { bathed }\end{array}$ & Edema & Edema [64] \\
\hline $\begin{array}{l}\text { Acacia mellifera } \\
\text { (M.Vahl) Benth. }\end{array}$ & Kithiia & Shrub & 0.02 & Bark & $\begin{array}{l}\text { An infusion is drunk, } \\
\text { sometimes mixed with } \\
\text { the bark of Lannea } \\
\text { schweinfurthii }\end{array}$ & Gonorrhea & References $[1,66]$ \\
\hline
\end{tabular}


TABle 3: Continued.

\begin{tabular}{|c|c|c|c|c|c|c|c|}
\hline $\begin{array}{l}\text { Family and species } \\
\text { name }\end{array}$ & Local name & Habit & RFC & $\begin{array}{c}\text { Parts } \\
\text { collected }\end{array}$ & $\begin{array}{l}\text { Drug preparation and } \\
\text { administration }\end{array}$ & Disease treated & $\begin{array}{c}\text { Relevant reported disease } \\
\text { treated or use }\end{array}$ \\
\hline $\begin{array}{l}\text { Acacia nilotica (L.) } \\
\text { Delile }\end{array}$ & Kisemei & Tree & 0.54 & Bark & $\begin{array}{l}\text { Chewed and extracts } \\
\text { swallowed. An } \\
\text { infusion is } \\
\text { alternatively drunk }\end{array}$ & $\begin{array}{l}\text { Cough, chest } \\
\text { pains, malaria, } \\
\text { pneumonia }\end{array}$ & $\begin{array}{c}\text { Malaria, cough, chest } \\
\text { pains, and pneumonia } \\
{[1,34,42,44,64,66]}\end{array}$ \\
\hline $\begin{array}{l}\text { Acacia tortilis } \\
\text { (Forssk.) Hayne }\end{array}$ & Mwaa & Tree & 0.25 & Bark, root & $\begin{array}{l}\text { Fresh root is dried in } \\
\text { hot ash and smoked } \\
\text { like a cigarette as a } \\
\text { remedy for flu. The } \\
\text { bark is chewed against } \\
\text { cough and pneumonia. } \\
\text { Alternatively, an } \\
\text { infusion from the bark } \\
\text { is drunk }\end{array}$ & $\begin{array}{l}\text { Flu, cough, and } \\
\text { pneumonia }\end{array}$ & Cough and colds $[29,64]$ \\
\hline $\begin{array}{l}\text { Albizia } \\
\text { anthelmintica } \\
\text { Brongn. }\end{array}$ & Kyoa kisamba & Tree & 0.25 & Bark & $\begin{array}{l}\text { An infusion is steam } \\
\text { bathed against edema } \\
\text { and drunk against } \\
\text { tapeworm, gonorrhea, } \\
\text { and measles. The bark } \\
\text { is burnt into charcoal } \\
\text { and ground into a } \\
\text { powder which is } \\
\text { applied on septic } \\
\text { wounds }\end{array}$ & $\begin{array}{l}\text { Edema, } \\
\text { tapeworm, } \\
\text { gonorrhea, } \\
\text { measles, and } \\
\text { wounds }\end{array}$ & 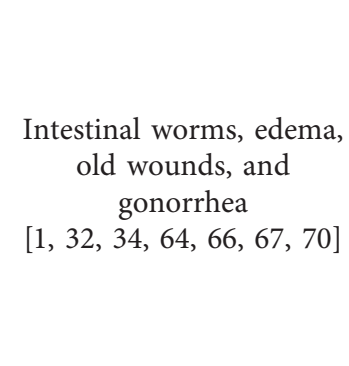 \\
\hline $\begin{array}{l}\text { Cassia abbreviata } \\
\text { Oliv. }\end{array}$ & Kyalandathe & Tree & 0.63 & $\begin{array}{l}\text { Aerial parts, } \\
\text { bark }\end{array}$ & $\begin{array}{l}\text { Aerial parts are chewed } \\
\text { and the juice retained } \\
\text { in the mouth as a } \\
\text { remedy for toothache. } \\
\text { A decoction or an } \\
\text { infusion from the stem } \\
\text { or bark is drunk } \\
\text { against cough, malaria, } \\
\text { gonorrhea, kidney } \\
\text { pains, colds, and pain } \\
\text { in joints }\end{array}$ & $\begin{array}{l}\text { Toothache, } \\
\text { cough, malaria, } \\
\text { gonorrhea, } \\
\text { kidney pains, } \\
\text { colds, and pain } \\
\text { in joints }\end{array}$ & $\begin{array}{l}\text { Gonorrhea, malaria, } \\
\text { pneumonia and chest } \\
\text { complaints }[1,66]\end{array}$ \\
\hline $\begin{array}{l}\text { Delonix elata (L.) } \\
\text { Gamble }\end{array}$ & Mwaange & Tree & 0.02 & Bark & $\begin{array}{l}\text { Dried and ground into } \\
\text { a powder and topically } \\
\text { applied }\end{array}$ & Septic wounds & Wounds [64]. \\
\hline $\begin{array}{l}\text { Dichrostachys } \\
\text { cinerea (L.) Wight } \\
\text { and Arn. }\end{array}$ & $\begin{array}{l}\text { Munoa- } \\
\text { mathoka }\end{array}$ & Shrub & 0.02 & Bark & $\begin{array}{l}\text { Chewed and the } \\
\text { extracts swallowed }\end{array}$ & Cough & Cough [64] \\
\hline $\begin{array}{l}\text { Entada } \\
\text { leptostachya } \\
\text { Harms }\end{array}$ & Mwaitha & Climber & 0.10 & $\begin{array}{l}\text { Exudate, } \\
\text { root }\end{array}$ & $\begin{array}{l}\text { The exudate is applied } \\
\text { into an injured eye. A } \\
\text { root infusion is taken } \\
\text { in case of food } \\
\text { poisoning or a snake } \\
\text { bite. A root poultice is } \\
\text { used to message the } \\
\text { body in case of an } \\
\text { internal injury }\end{array}$ & $\begin{array}{c}\text { Eye injury, } \\
\text { food } \\
\text { poisoning, } \\
\text { snake bite, and } \\
\text { internal injury }\end{array}$ & $\begin{array}{c}\text { Snake bites, cuts, arrow } \\
\text { poisoning and eye injuries } \\
{[29,34,64]}\end{array}$ \\
\hline $\begin{array}{l}\text { Indigofera } \\
\text { lupatana Baker } \mathrm{f} .\end{array}$ & Muthika & Shrub & 0.10 & Bark & $\begin{array}{l}\text { An infusion from the } \\
\text { root bark is drunk for } \\
\text { cough, diarrhea, and } \\
\text { constipation. The root } \\
\text { bark is alternatively } \\
\text { chewed and the } \\
\text { extracts swallowed }\end{array}$ & $\begin{array}{l}\text { Cough, } \\
\text { diarrhea, and } \\
\text { constipation }\end{array}$ & $\begin{array}{c}\text { Cough and stomach-ache } \\
{[29,34,64]}\end{array}$ \\
\hline $\begin{array}{l}\text { Senna occidentalis } \\
\text { (L.) Link }\end{array}$ & Musingili & Herb & 0.04 & Root & An infusion is drunk & $\begin{array}{l}\text { Stomach-ache } \\
\text { and diarrhea }\end{array}$ & $\begin{array}{c}\text { Stomach-ache and } \\
\text { diarrhea }[1,15]\end{array}$ \\
\hline
\end{tabular}


TABle 3: Continued.

\begin{tabular}{|c|c|c|c|c|c|c|c|}
\hline $\begin{array}{l}\text { Family and species } \\
\text { name }\end{array}$ & Local name & Habit & RFC & $\begin{array}{c}\text { Parts } \\
\text { collected }\end{array}$ & $\begin{array}{l}\text { Drug preparation and } \\
\text { administration }\end{array}$ & Disease treated & $\begin{array}{c}\text { Relevant reported disease } \\
\text { treated or use }\end{array}$ \\
\hline $\begin{array}{l}\text { Tamarindus indica } \\
\text { L. }\end{array}$ & Kithumula & Tree & 0.19 & Leaf, fruit & $\begin{array}{l}\text { An infusion from the } \\
\text { fruit is drunk against } \\
\text { tonsillitis. The tonsils } \\
\text { are also massaged with } \\
\text { leaf and fruit poultice. } \\
\text { An infusion of fruits } \\
\text { and leaves is drunk and } \\
\text { bathed against } \\
\text { smallpox, measles, and } \\
\text { edema }\end{array}$ & $\begin{array}{l}\text { Tonsillitis, } \\
\text { smallpox, } \\
\text { measles, and } \\
\text { edema }\end{array}$ & $\begin{array}{c}\text { Coughs, throat, measles, } \\
\text { chicken pox, edema, sore } \\
\text { throat, and oral thrush } \\
{[1,64]}\end{array}$ \\
\hline $\begin{array}{l}\text { Tephrosia villosa } \\
\text { (L.) Pers. } \\
\text { Loganiaceae }\end{array}$ & Mwenyu & Herb & 0.02 & Root & A decoction is drunk & Malaria & Fever $[44]$ \\
\hline $\begin{array}{l}\text { Strychnos } \\
\text { henningsii Gilg }\end{array}$ & Muteta & Tree & 0.46 & Bark, leaf & $\begin{array}{l}\text { An infusion is drunk } \\
\text { or powder from dried } \\
\text { leaves and bark is } \\
\text { infused in hot drinks }\end{array}$ & $\begin{array}{l}\text { Malaria, } \\
\text { constipation, } \\
\text { pneumonia, } \\
\text { kidney pains }\end{array}$ & $\begin{array}{c}\text { Body pains, malaria, } \\
\text { pneumonia, chest pains, } \\
\text { and stomach-ache } \\
{[1,32,34,64]}\end{array}$ \\
\hline \multicolumn{8}{|l|}{ Malvaceae } \\
\hline $\begin{array}{l}\text { Grewia tembensis } \\
\text { Fresen. }\end{array}$ & Mutuva & Shrub & 0.04 & Bark & $\begin{array}{l}\text { A decoction is drunk } \\
\text { or the roots dried, } \\
\text { ground into a powder, } \\
\text { and infused in hot } \\
\text { drinks }\end{array}$ & $\begin{array}{l}\text { Reduced } \\
\text { appetite, } \\
\text { swollen } \\
\text { diaphragm }\end{array}$ & $\begin{array}{l}\text { Heartburn and cough } \\
{[64,65]}\end{array}$ \\
\hline $\begin{array}{l}\text { Grewia } \\
\text { tephrodermis } \\
\text { K.Schum. }\end{array}$ & Mulawa & Shrub & 0.06 & $\begin{array}{l}\text { Roots, aerial } \\
\text { parts }\end{array}$ & $\begin{array}{l}\text { A root decoction is } \\
\text { drunk against } \\
\text { diarrhea, stomach- } \\
\text { ache, and as an } \\
\text { aphrodisiac in men. } \\
\text { An infusion from the } \\
\text { aerial parts is steam } \\
\text { bathed for edema and } \\
\text { skin rashes }\end{array}$ & $\begin{array}{l}\text { Diarrhea, } \\
\text { stomach-ache, } \\
\text { aphrodisiac in } \\
\text { men, edema, } \\
\text { skin rashes }\end{array}$ & $\begin{array}{l}\text { Dermatitis, diarrhea and } \\
\text { restoring female fertility } \\
\qquad[1,29,64]\end{array}$ \\
\hline $\begin{array}{l}\text { Grewia villosa } \\
\text { Willd. }\end{array}$ & Muvu & Shrub & 0.06 & Root & An infusion is drunk & Diarrhea & $\begin{array}{c}\text { Diarrhea, stomach-ache, } \\
\text { and amoeboid dysentery } \\
{[1,64,66]}\end{array}$ \\
\hline $\begin{array}{l}\text { Sterculia africana } \\
\text { (Lour.) Fiori } \\
\text { Meliaceae }\end{array}$ & Kiusya & & 0.13 & $\begin{array}{l}\text { Bark, aerial } \\
\text { parts }\end{array}$ & An infusion is drunk & Diarrhea & $\begin{array}{l}\text { Diarrhea and } \\
\text { dysentery [1] }\end{array}$ \\
\hline $\begin{array}{l}\text { Melia volkensii } \\
\text { Gürke } \\
\text { Menispermaceae }\end{array}$ & Mukau & Tree & 0.04 & Leaf & $\begin{array}{l}\text { A decoction is drunk } \\
\text { and bathed }\end{array}$ & Malaria, edema & $\begin{array}{c}\text { Edema and } \\
\text { malaria }[34,64]\end{array}$ \\
\hline $\begin{array}{l}\text { Chasmanthera } \\
\text { dependens Hochst. }\end{array}$ & Usyiii & Liana & 0.04 & Stem & An infusion is drunk & Diarrhea & Reference [60] \\
\hline $\begin{array}{l}\text { Cissampelos } \\
\text { pareira L. } \\
\text { Moraceae }\end{array}$ & Kutu kumwe & Climber & 0.15 & Root & An infusion is drunk & $\begin{array}{l}\text { Diarrhea, } \\
\text { stomach-ache }\end{array}$ & $\begin{array}{l}\text { Stomach } \\
\text { ailments }[1,44]\end{array}$ \\
\hline $\begin{array}{l}\text { Ficus sycomorus } L . \\
\text { Moringaceae }\end{array}$ & Mukuyu & Tree & 0.02 & Exudate & Applied on tooth & Toothache & Toothache $[1,44]$ \\
\hline $\begin{array}{l}\text { Moringa borziana } \\
\text { Mattei }\end{array}$ & Mululo & Shrub & 0.17 & Root & $\begin{array}{l}\text { An infusion is bathed } \\
\text { against edema and } \\
\text { drunk for malaria and } \\
\text { gonorrhea. The roots } \\
\text { are alternatively dried } \\
\text { and ground into a } \\
\text { powder which is } \\
\text { infused in hot drinks }\end{array}$ & $\begin{array}{l}\text { Edema, } \\
\text { malaria, and } \\
\text { gonorrhea }\end{array}$ & References $[71,72]$ \\
\hline Phyllanthaceae & & & & & & & \\
\hline
\end{tabular}


TABle 3: Continued.

\begin{tabular}{|c|c|c|c|c|c|c|c|}
\hline $\begin{array}{l}\text { Family and species } \\
\text { name }\end{array}$ & Local name & Habit & RFC & $\begin{array}{c}\text { Parts } \\
\text { collected }\end{array}$ & $\begin{array}{l}\text { Drug preparation and } \\
\text { administration }\end{array}$ & Disease treated & $\begin{array}{c}\text { Relevant reported disease } \\
\text { treated or use }\end{array}$ \\
\hline $\begin{array}{l}\text { Bridelia taitensis } \\
\text { Vatke and Pax ex } \\
\text { Pax }\end{array}$ & Kyaanthya & Tree & 0.02 & Leaf & $\begin{array}{l}\text { Is used as a bandage } \\
\text { after application of } \\
\text { herbal medicine in the } \\
\text { form of a powder }\end{array}$ & Septic wounds & Reference [1] \\
\hline \multicolumn{8}{|l|}{ Plumbaginaceae } \\
\hline $\begin{array}{l}\text { Plumbago } \\
\text { zeylanica L. }\end{array}$ & Wala & Shrub & 0.10 & Root & $\begin{array}{l}\text { A decoction is drunk, } \\
\text { sometimes mixed with } \\
\text { roots of Moringa } \\
\text { borziana }\end{array}$ & Gonorrhea & Gonorrhea [64] \\
\hline \multicolumn{8}{|l|}{ Rubiaceae } \\
\hline $\begin{array}{l}\text { Hymenodictyon } \\
\text { parvifolium Oliv. }\end{array}$ & Mulinditi & Shrub & 0.02 & Root & $\begin{array}{c}\text { An infusion is steam } \\
\text { bathed }\end{array}$ & Edema & Edema [64] \\
\hline $\begin{array}{l}\text { Tennantia sennii } \\
\text { (Chiov.) Verdc. } \\
\text { and Bridson }\end{array}$ & Kisilingu & Shrub & 0.08 & Root & A decoction is drunk & $\begin{array}{l}\text { Diarrhea, } \\
\text { malaria, } \\
\text { impotence, and } \\
\text { infertility }\end{array}$ & $\begin{array}{l}\text { Literature not } \\
\text { found }\end{array}$ \\
\hline \multicolumn{8}{|l|}{ Rutaceae } \\
\hline $\begin{array}{l}\text { Vepris simplicifolia } \\
\text { (Engl.) Mziray }\end{array}$ & Mutuyu & Tree & 0.10 & $\begin{array}{l}\text { Leaf, bark, } \\
\text { root }\end{array}$ & $\begin{array}{c}\text { An infusion is drunk } \\
\text { and } \\
\text { steam bathed }\end{array}$ & Edema, malaria & $\begin{array}{l}\text { General body pains, } \\
\text { malaria, and pleurisy } \\
{[1,17,34,36,64,66]}\end{array}$ \\
\hline $\begin{array}{l}\text { Zanthoxylum } \\
\text { chalybeum Engl. }\end{array}$ & Mukenea & Tree & 0.27 & Bark, fruit & $\begin{array}{l}\text { The root bark poultice } \\
\text { is applied on an aching } \\
\text { tooth as a remedy for } \\
\text { toothache. An infusion } \\
\text { from the bark or fruit } \\
\text { is drunk against } \\
\text { malaria, edema and } \\
\text { cough. Alternatively, } \\
\text { the bark, and the fruit } \\
\text { are ground into a } \\
\text { powder which is } \\
\text { infused in hot drinks }\end{array}$ & $\begin{array}{l}\text { Toothache, } \\
\text { malaria, } \\
\text { edema, and } \\
\text { cough }\end{array}$ & $\begin{array}{c}\text { Malaria, edema, cough, } \\
\text { and toothache } \\
{[1,17,29,34,64,66]}\end{array}$ \\
\hline \multicolumn{8}{|l|}{ Solanaceae } \\
\hline $\begin{array}{l}\text { Solanum } \\
\text { campylacanthum } \\
\text { Hochst. }\end{array}$ & Kitongu & Shrub & 0.15 & Root, fruit & $\begin{array}{l}\text { An infusion from the } \\
\text { root is drunk against } \\
\text { diarrhea. Juice from a } \\
\text { fruit is retained in the } \\
\text { mouth as a remedy for } \\
\text { toothache. Juice from a } \\
\text { ripe fruit is applied } \\
\text { topically on body parts } \\
\text { infected with } \\
\text { ringworms }\end{array}$ & $\begin{array}{l}\text { Diarrhea, } \\
\text { toothache, and } \\
\text { ringworms }\end{array}$ & $\begin{array}{l}\text { Stomach-ache, diarrhea, } \\
\text { amoeboid dysentery, } \\
\text { toothache, and ringworms } \\
{[1,32-34,41,64,66,73]}\end{array}$ \\
\hline $\begin{array}{l}\text { Solanum tettense } \\
\text { Klotzsch } \\
\text { Vitaceae }\end{array}$ & Mutongatongu & Shrub & 0.02 & Root & A decoction is drunk & $\begin{array}{l}\text { Diarrhea and } \\
\text { stomach-ache }\end{array}$ & Stomach-ache [64] \\
\hline $\begin{array}{l}\text { Cissus aphyllantha } \\
\text { Gilg }\end{array}$ & Muvelengwa & Liana & 0.06 & Root & $\begin{array}{l}\text { An infusion is used as a } \\
\text { head wash in case of } \\
\text { headache and drunk } \\
\text { against diarrhea and } \\
\text { pneumonia }\end{array}$ & $\begin{array}{l}\text { Headache, } \\
\text { diarrhea, and } \\
\text { pneumonia }\end{array}$ & $\begin{array}{c}\text { Diarrhea and amoeboid } \\
\text { dysentery }[34,64]\end{array}$ \\
\hline $\begin{array}{l}\text { Cissus rotundifolia } \\
\text { Vahl }\end{array}$ & Itulu & Liana & 0.02 & Leaf & $\begin{array}{c}\text { A poultice is used as a } \\
\text { bandage }\end{array}$ & Septic wounds & $\begin{array}{c}\text { Septic body swellings, } \\
\text { boils, and used as ear drops } \\
{[32,44]}\end{array}$ \\
\hline Xanthorrhoeaceae & & & & & & & \\
\hline
\end{tabular}


TABLE 3: Continued.

\begin{tabular}{|c|c|c|c|c|c|c|c|}
\hline $\begin{array}{l}\text { Family and species } \\
\text { name }\end{array}$ & Local name & Habit & RFC & $\begin{array}{c}\text { Parts } \\
\text { collected }\end{array}$ & $\begin{array}{l}\text { Drug preparation and } \\
\text { administration }\end{array}$ & Disease treated & $\begin{array}{l}\text { Relevant reported disease } \\
\text { treated or use }\end{array}$ \\
\hline $\begin{array}{l}\text { Aloe secundiflora } \\
\text { Engl. }\end{array}$ & & Herb & 0.31 & $\begin{array}{l}\text { Exudate, } \\
\text { inflorescence }\end{array}$ & $\begin{array}{l}\text { An infusion of the } \\
\text { exudate is drunk } \\
\text { against malaria, cough, } \\
\text { peptic ulcers, and a } \\
\text { swelling of the } \\
\text { diaphragm. The } \\
\text { peduncle of the } \\
\text { inflorescence is } \\
\text { alternatively burnt to } \\
\text { charcoal and ground } \\
\text { into a powder which is } \\
\text { licked or infused in hot } \\
\text { drinks. An exudate } \\
\text { from the leaf is } \\
\text { dropped on septic } \\
\text { wounds }\end{array}$ & $\begin{array}{l}\text { Malaria, cough, } \\
\text { peptic ulcers, } \\
\text { swelling of the } \\
\text { diaphragm, } \\
\text { and wounds }\end{array}$ & $\begin{array}{c}\text { Malaria, diarrhea, ulcers, } \\
\text { swollen diaphragm, open } \\
\text { wounds, and lack of } \\
\text { appetite } \\
{[1,29,34,38,64,67,73]}\end{array}$ \\
\hline $\begin{array}{l}\text { Zygophyllaceae } \\
\text { Balanites } \\
\text { aegyptiaca (L.) } \\
\text { Delile }\end{array}$ & Kilului & Tree & 0.08 & Fruit & $\begin{array}{l}\text { The pulp of a ripe fruit } \\
\text { is eaten }\end{array}$ & $\begin{array}{l}\text { Colds, cough, } \\
\text { and } \\
\text { kwashiorkor }\end{array}$ & $\begin{array}{l}\text { Kwashiorkor, cough, and } \\
\text { chest complaints }[1,29,66]\end{array}$ \\
\hline
\end{tabular}

indication that it is not being transferred or is acquired after a long period of time. This is further supported by Nanyingi et al. [36] who found that the knowledge on the treatment of some diseases was possessed by the elder members of the society. There are reports that in some regions of Kenya, the young generations are ignorant of traditional practices after taking up formal education $[37,45]$. However, external factors such as education may not negatively affect the sustainability of traditional knowledge in people who have already acquired it [75]. It is likely that there exists a barrier limiting the transfer of traditional knowledge between the old and the young generations, a complexity that needs elaboration in future studies.

4.2. Medicinal Flora. Leguminosae was the dominant plant family reported during the study followed by Euphorbiaceae and Lamiaceae. Leguminosae was also reported to be among the frequently used plant families in treatment of malaria in Kwale community [78] and in the management of HIV/AIDS in Mfangano Island in Kenya [15]. In the study of medicinal plants used by the Marakwet community, Mimosaceae was the dominant plant family reported [79] while in the study of medicinal plants of Tana river county, Euphorbiaceae, Leguminosae, and Lamiaceae were found to be among the frequently used plant families [30, 77]. In the flora of Kitui county, Leguminosae is the largest plant family [46]. It is also the largest plant family in the flora of Kenya [24]. African legumes are tolerant to drought and therefore comprise important resources for people living in arid areas [80]. Considering the amount of rainfall received in drylands of Kenya [81] and its elevational range [25], Kitui county can be considered as a typical dryland region; hence the large number of legumes could be attributed to the arid conditions of the area.

Shrubs and trees were the dominant life forms reported, which agrees with the results of another study in Kenya [36].
An ethnobotanical study among the Marakwet community in Kenya reported trees to be the frequently used plant life forms [79] while among the Kwale people of Kenya, shrubs were found to be frequently utilized for the treatment of malaria [78]. In mount Elgon, a study of medicinal plants reported that trees were the dominant life forms used followed by shrubs [41]. Generally, the vegetation of the study area is dominated mostly by dry forests composed of shrubs $[46,56,64]$. Shrubs can also be obtained from many areas including bushlands and farmlands [44], making it easier for the local communities to access them.

In this study, roots and barks were found to be frequently collected for herbal medicine. A single plant species may have several parts collected for herbal medicine [82] which was also reported during the study. Some plant species were reported to be used as whole plants. The use of the whole plants in Kenya is reported to be applied in cases of small plants, herbaceous plants, or epiphytes [44]. In a similarly arid region in Kenya, roots and barks were found to be frequently collected for herbal medicine [45]. In a study of medicinal plants used by the Sabaot people of mount Elgon, roots were found to be frequently utilized followed by the barks and leaves [41]. Moreover, in a survey of medicinal plants in the urban areas of Kenya, roots and barks were found to be the common plant parts sold [21]. In some studies, leaves are reported to be frequently collected with significant proportions of barks and roots being reported [34, 82, 83]. According to Malonza et al. [46], debarking and uprooting are some of the common techniques of harvesting medicinal plants used by the people of Kitui. Harvesting of root and bark increases the level of vulnerability of plants since the two parts take a longer time to regenerate when compared to the leaves; hence the chances of survival of debarked trees are rare $[34,47]$. Debarked plants are likely to be in danger of overexploitation; hence their conservation 


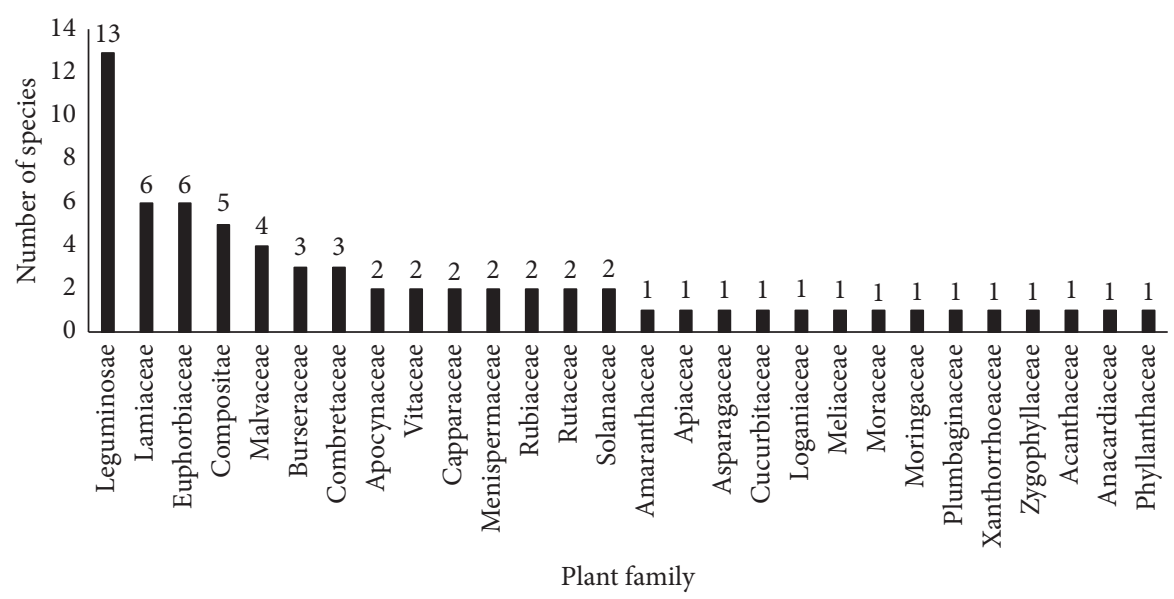

FIgURE 2: Distribution of plant species in different families.

status needs further investigation [82]. Since plants found in dry areas are perceived to be of better medicinal quality, they are preferred for collection by traders and herbalists, thus risking degradation due to their high demand [84]. In the semiarid areas of Kenya, the effects of overutilization, desertification, and global warming have subjected biodiversity to increased pressure [45]. A combination of such factors with the vulnerable nature of semiarid lands may lead to further reduction of habitats which harbor medicinal plants [67]. Therefore, substituting the roots and barks with plant parts such as leaves and aerial parts may reduce the pressure exerted on medicinal plants [47]. In addition, bioactive compounds from plants are mostly extracted using water $[41,45]$ whose efficacy may be low compared to other media such as methanol, suggesting that ineffective media for extracting plant-based compounds may lead to wastage of the harvested materials; hence traditional healers need to be trained on other potential effective methods [45]. Conservation initiatives of the plant species endangered by overexploitation are therefore necessary [46] and Mutomo hill plant sanctuary is potentially a suitable area for such initiatives in Kitui county.

There were 24 plant species frequently collected by the herbalists in the study area, all of which can be treated as priority plants based on Njoroge et al. [40]. From this study, five plant species (Zanthoxylum chalybeum, Terminalia brownii, Croton megalocarpus, Albizia anthelmintica, and Aloe secundiflora) have been reported as priority medicinal plants elsewhere in Kitui county [40]. Zanthoxylum and Strychnos species are also among the most preferred plant species for herbal medicine in Kitui county [46]. Acacia nilotica and Strychnos henningsii were also found to be among the most popular plant species used in the management of respiratory infections at Kibwezi, an area adjacent to Mutomo subcounty [45]. As reported in a previous study [41], most of the plant species were obtained from the wild. In this study, all the Commiphora species were found to be cultivated by some informants as hedge plants especially along fences. This is because Commiphora species can be propagated easily from cuttings since they root easily once driven into the ground [60]. Cultivation of plants as live fences has been undertaken by some local communities in Kenya as a way of preserving scarce medicinal plants [36]. Other plant species cultivated were Aloe secundiflora, Croton megalocarpus, and Melia volkensii. The herbalists reported an increasing scarcity of Strychnos henningsii and Vepris simplicifolia, relating it to land conversion for farmlands and private development. The decline of Strychnos henningsii in the wild was previously reported in Kitui county [40]. Due to the increasing scarcity of medicinal plants, some herbalists reported retaining Terminalia brownii, Tamarindus indica, Balanites aegyptiaca, and Moringa borziana in their farmlands for future medicinal uses. Njoroge et al. [40] also reported that Terminalia brownii, Croton megalocarpus, and Aloe secundiflora were preserved in the farmlands for future medicinal uses. The abundance of useful plants has been reported to decline as a result of fluctuating rainfall patterns and anthropogenic activities such as selective harvesting, overexploitation, and expansion of farmlands [85]. In Kitui county, Acacia tortilis and Terminalia brownii are also reported to be used for charcoal [34] which may further reduce their abundance in the wild. Some medicinal plants found in this study such as Zanthoxylum chalybeum and Albizia anthelmintica are also sold in the urban areas of Kenya [21]. During the study, Cassia abbreviata, Terminalia brownii, and Vepris simplicifolia were found to be sold in Mutomo market. Several important collection sites for medicinal plants in Kenya are reported to have been converted into farmlands [86]. In an ethnobotanical study in Zanzibar, the abundance of some medicinal plants is reported to have decreased making it difficult to obtain them from the wild [87]. The supply of medicinal plant products sold in the Kenyan urban centers is also decreasing [21]. Amir et al. [88] reported that few people in Tanzania cultivated medicinal Aloe species and that most of them were being obtained from the wild, resulting in the decline of wild Aloe populations. Aloe species in Kenya, are however threatened by factors related to the increase in human and livestock populations and international trade rather than utilization for herbal medicinal [89]. Generally, medicinal plants in Kenya are threatened by both natural and anthropogenic factors where the majority of them have declined due to deforestation [36]. 


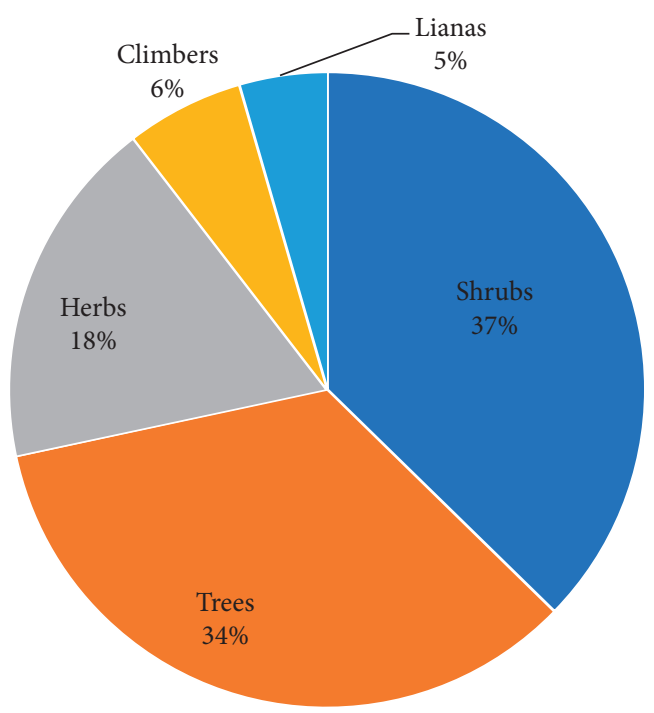

FIGURE 3: Distribution of plant growth habits.

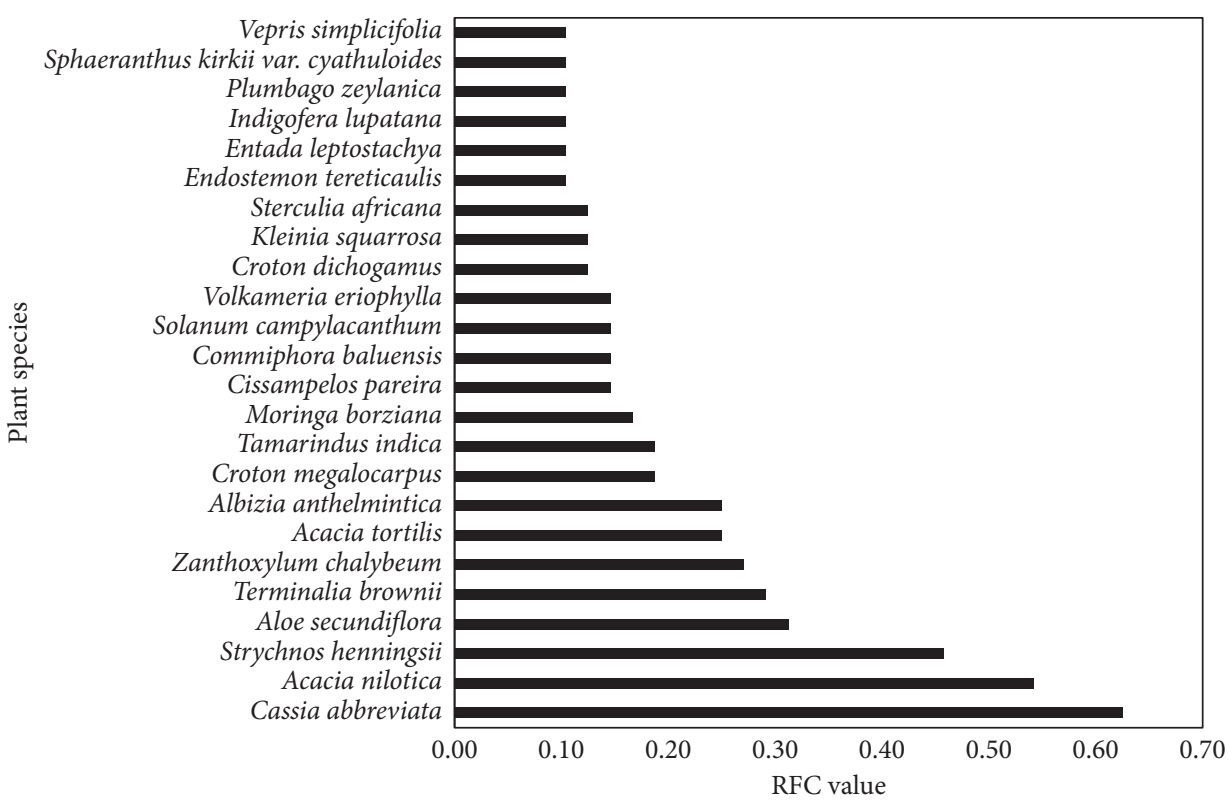

FIGURE 4: Frequently used plant species.

4.3. Medicinal Uses. The medicinal applications of most of the plant species reported in this study have been reported before although the diseases treated, the parts used, the methods of preparation, and administration of the drugs may differ in some instances. A previous study reported on novel therapeutic applications of some plant species in Kenya [41]. However, further botanical investigations of voucher collections stored in various herbaria are necessary before conclusions can be arrived at. Plant species belonging to the same genus may be used for the management of similar health conditions. Such species may have the same local names such as those of genus Sphaeranthus, which are reported to be used in the treatment of malaria and edema [64]. Morgan [65] also found out that the same local names were being applied by the local community to refer to
Indigofera and Crotalaria species. During the field survey, an herbalist mentioned that Indigofera arrecta and I. lupatana could at times be confused since the two plants share the same local name in the study area. Substituting I. arrecta with I. lupatana was sometimes applicable although the latter was reported to be more effective. Phytochemical investigations to determine the effectiveness of the two species in the management of the said ailments are therefore in need. Some cases of health management involved the treatment of symptoms of the reported ailments. For example, reduced appetite was reported to be a symptom of a swollen diaphragm; hence the two conditions were managed simultaneously. Some cases of herbal preparations involved mixing of different plant species, which the herbalists claimed was a remedy for notorious diseases or a suspected 
TABLe 4: Classifications of diseases reported in Mutomo hill plant sanctuary and its environs.

\begin{tabular}{|c|c|c|}
\hline Disease categories & Disorders reported & $\begin{array}{c}\text { Number of plant } \\
\text { taxa used }\end{array}$ \\
\hline Infections or infestations & $\begin{array}{c}\text { Gonorrhea, ringworms, tapeworms, pinworms, tuberculosis, yellow fever, malaria, } \\
\text { measles, small pox, colds, pneumonia, and flu }\end{array}$ & 33 \\
\hline Digestive system disorders & Diarrhea, peptic ulcers, stomach-ache, constipation, and toothache & 24 \\
\hline Body abnormalities & Edema "body swelling" & 19 \\
\hline Respiratory system disorders & Swollen diaphragm, cough, chest pains, tonsillitis, and swelling of the diaphragm & 15 \\
\hline Body injuries & $\begin{array}{c}\text { Boils, foreign objects pierced into the body, septic wounds, fresh cuts, and internal } \\
\text { injuries }\end{array}$ & 13 \\
\hline Genitourinary system disorders & Kidney pains, aphrodisiacs, impotence, and infertility & 7 \\
\hline $\begin{array}{l}\text { Muscular-skeletal system } \\
\text { disorders }\end{array}$ & Back pains, pain in joints, and headache & 4 \\
\hline Nutritional disorders & Kwashiorkor, reduced appetite & 4 \\
\hline Sensory system disorders & Eye problems, earache & 3 \\
\hline $\begin{array}{l}\text { Skin/subcutaneous cellular } \\
\text { tissue disorders }\end{array}$ & Warts, skin rashes & 2 \\
\hline Circulatory system disorders & Hypertension & 1 \\
\hline Poisonings & Snake bites, food poisoning & 1 \\
\hline Ethnoveterinary applications & Diarrhea in livestock, tick infestation, eye problems, liver diseases, lung diseases & 12 \\
\hline
\end{tabular}

combination of two diseases. Mixing of medicinal plants for the treatment of a single ailment has been reported in other studies $[32,36]$. In addition, some herbal products sold in Kenyan urban areas for the treatment of some diseases are prepared mixed [21]. Since the efficacies of most plant species used in traditional medicine have not been tested, their role in disease management cannot be ascertained [45]. Ethnobotanical studies in Kenya are also considered few in light of the high plant diversity in the country [36]. Although literature reveals that an enormous data on medicinal plants of Kenya exist [1], ethnomedicinal applications of some plant species have not been documented to date. As a result, Njoroge et al. [40] emphasized the need for the documentation of ethnomedicinal uses of regional floras.

Infections and digestive system disorders are treated with most of the medicinal plant species in some parts of Kenya [32, 34]. Tuberculosis was reported to be managed by chewing the leaves of Combretum hereroense and swallowing the extract. Tuberculosis is a bacterial disease majorly affecting the lungs although it has been reported to advance to the ears and the tonsils especially in Africa [90-92]. Earache and tonsillitis were also reported to be managed using herbal medicines. However, based on this ethnobotanical survey, the relationship between tuberculosis and such ailments cannot be ascertained. Acacia nilotica, A. tortilis, Strychnos henningsii, and Cissus aphyllantha were reported to be used for the treatment of pneumonia. Acacia nilotica and Strychnos henningsii have been found to show efficacy against the pathogens causing respiratory infections including pneumonia [45]. Pneumonia is reportedly the leading disease in childhood mortality, especially in marginalized communities of developing countries [93]. In recent years, respiratory infections have become resistant to antibiotics, resulting in ineffectiveness in their treatment which has led to advocacy in search of plant-based antimicrobial drugs $[45,82,94]$. Decoctions of Lannea schweinfurthii and Plumbago zeylanica were reported for the treatment of gonorrhea. A similar application of Lannea schweinfurthii has been reported before [64]. One herbalist admitted to advising his family members to take a decoction of Lannea schweinfurthii against gonorrhea at least once a month to avoid the chances of contracting the disease. It is likely that the local herbalists are aware of the adverse effects associated with the disease especially in women in spite of its asymptomatic nature [95]. Gonorrhea pathogen is reported to show resistance to clinical therapies [96]; hence medicinal plants may offer other opportunities for the development of novel drugs against such infections.

Some herbalists reported that pain in joints, general body pains, and headache were symptoms of malaria. These conditions together with malaria were therefore managed by the herbalists using the same medicinal plants. Although such ailments are categorized under muscular-skeletal disorders, their association with malaria has been reported in other studies in Kenya [97, 98]. Cassia abbreviata and Albizia anthelmintica which were reported for the treatment of malaria have been reported to have no or a weak antiplasmodial activity; hence they are likely to be applied in the treatment of conditions that accompany malaria [99]. Plant species such as Strychnos henningsii, Aloe secundiflora, and Zanthoxylum chalybeum which have been reported for the treatment of chronic joint pains [100] were reported for treatment of malaria during the study. A bath from an infusion of Kleinia squarrosa was also reported to be used against malaria. Chemical analysis of Kleinia squarrosa has revealed that essential oils from the plant contain volatile compounds that act as mosquito repellants [101] which further supports its application in the management of mosquito-related ailments. Malaria was reported to be treated through the administration of decoctions, infusions, and bathes. Historical treatments of malaria with plantbased derivatives are the use of quinine and artemisinin as antimalarial drugs [97]. Treatment of malaria with medicinal plants is also widely reported in Kenya [17, 98]. Some 
medicinal plants which were reported for treatment of malaria such as Vepris simplicifolia and Zanthoxylum chalybeum have proven antiplasmodial activities [99]. Malaria is a major hindrance to economic growth in Sub-Saharan Africa [102] and it is also among the leading diseases in childhood mortality and in deaths of pregnant mothers in Africa [93]. In recent years, it has become difficult to treat malaria owing to the development of plasmodial resistance against the available clinical drugs [103]. The high prevalence of malaria infection in rural areas of Kenya has led the local communities to rely on medicinal plants, with some rural inhabitants reporting them to be more effective and cheaper compared to clinical therapies [98].

Viral infections reported during the study to be managed using medicinal plants included yellow fever, measles, smallpox, colds, and flu. Common colds are caused by numerous viruses belonging to different families and they display varying clinical manifestations. Influenzas, the viruses causing flu are among the viruses associated with common colds. A universal mode of treatment and prevention of the disorders arising from common colds has not been developed due to the varying pathogenic mechanisms of the viruses [104]. Yellow fever was reported to be treated through bathing an infusion of Terminalia brownii, as previously reported $[34,60]$. Yellow fever is a disease in tropical South America and Africa with no specific treatment and is currently managed using vaccines $[105,106]$. Tamarindus indica was reported for the treatment of measles and smallpox by consumption of the fruits, steam bathing, or by taking an infusion from the fruit and leaves, as reported elsewhere [64]. In addition, a bath from an infusion of Kleinia squarrosa was also reported to treat smallpox and measles. According to two herbalists, cases of smallpox outbreak are nowadays rare. Vaccinations have effectively dealt with smallpox and are on the verge of eliminating measles, while the vaccine against yellow fever virus induces a long-term immunity once administered [107]. Other than vaccination, measles is prevented through supplementation of vitamin A $[108,109]$. However, Sub-Saharan Africa is classified by the $\mathrm{WHO}$ as a region with the highest rates of vitamin A deficiency [109]. Although control of some viral infections through vaccination has been effective, viruses still develop resistance to drugs making the treatment of associated diseases extremely difficult [110]. Hence the role of medicinal plants in the treatment of viral diseases cannot be neglected.

Taenia worms were reported to be primarily expelled using a decoction of Albizia anthelmintica, an application that has been quoted in various studies $[1,34,60,64]$. The plant is also reported to be antimicrobial [31]. In addition, an infusion of Commiphora edulis was reported to be used against tapeworms. Pinworm infestation was reported to be managed through exposure to smoke from burning seeds of Ricinus communis, an application that is likely to be facilitated by the poisonous nature of the seeds [1, 66]. Ringworms were reported to be treated with topical applications of exudate from Edithcolea grandis and the fruit juice of Solanum campylacanthum. Ringworms are fungal infections [62], locally referred to as "masilingi" by the local herbalists and infecting the surface of the skin. Solanum campylacanthum is reported to have an antifungal activity [111] supporting its ethnobotanical application in the treatment of ringworms. Skin ailments are mostly treated through direct topical application of herbal preparations [38] although a decoction of Terminalia prunioides was also reported to be drunk against ringworms.

Gastrointestinal problems are common health problems in rural areas of Kenya where in some ethnobotanical studies, they have been found to be managed with most of the medicinal plants surveyed $[32,86]$. According to the WHO, diarrhea is one of the world's leading killer diseases in children below the age of five [93]. The herbalists associated its outbreak with poor sanitary conditions especially dirty drinking water, which is also a major cause of diarrhea according to the United Nations Children's Fund [109]. Diarrhea was reported to be associated with stomach-ache and constipation as also reported elsewhere [42]. Those ailments were reported by the herbalists to be mostly managed using herbal infusions and decoctions. Some plant species reported for the treatment of gastrointestinal ailments such as Croton megalocarpus, Terminalia brownii, and Cissampelos pareira have been reported to have antimicrobial activities [31, 112, 113]. On two different accounts, the herbalists reported to advising pregnant mothers against taking infusions of Solanum campylacanthum and Cissampelos pareira for stomach problems as they might induce abortion. However, Solanum campylacanthum is reported to play important roles during labor and in maintaining pregnancy [13]. Although medicinal plants may have profound effects on pregnant mothers [114], they also play important roles in the development of fetus and in the health of the mothers [14]. Side effects of medicinal plants may result from improper dosage and the effects may be nonfatal [98]. Peptic ulcers were reported to be treated using an infusion of Aloe secundiflora or a decoction of Terminalia prunioides. Aloe secundiflora is reported to have an antimicrobial activity [115] which further supports its ethnobotanical application. Toothache was reported to be managed using Solanum campylacanthum, Zanthoxylum chalybeum, and Ficus sycomorus where the first two species are reported to have antimicrobial activities [111, 116]. Silver nanoparticles synthesized from the latex and leaves of Ficus sycomorus have been found to have a high antibacterial inhibition, proving that the plant has a potential in the treatment of bacterial infections [117]. However, according to one herbalist, the use of Ficus sycomorus latex for toothache is dangerous since it might spread in the mouth resulting in the loss of other teeth through corrosion which in turn leads to cracking and splitting of teeth into smaller pieces which fall with time.

Historically, the Kamba people of Kitui were semipastoralists $[55,58]$ and this culture has persisted to date [53]. Although the present study focused on documentation of medicinal plants used in the management of human diseases, the herbalists reported some plant species used for the management of livestock diseases (Table 5). Future studies are necessary to determine the diversity of plants used for the management of livestock 
TABLE 5: Plant species with ethnoveterinary applications in Mutomo hill plant sanctuary and its environs. Where possible, literature citing ethnoveterinary uses of the reported plant species has been indicated.

\begin{tabular}{|c|c|c|c|c|}
\hline Plant species & Part used & Ethnomedicinal applications & Disease treated & Reported ethnoveterinary uses \\
\hline $\begin{array}{l}\text { Commiphora } \\
\text { baluensis }\end{array}$ & Bark & An infusion & Diarrhea in poultry & Diarrhea in chicken [64] \\
\hline $\begin{array}{l}\text { Commiphora } \\
\text { habessinica }\end{array}$ & Exudate & Applied on areas infested with ticks & $\begin{array}{l}\text { Deticking agent in goats } \\
\text { and cattle }\end{array}$ & Is antiseptic [64] \\
\hline Boscia coriacea & $\begin{array}{l}\text { Leaves, } \\
\text { root }\end{array}$ & $\begin{array}{c}\text { An infusion is administered orally. The leaves } \\
\text { are burnt and ground into a powder which is } \\
\text { applied into the eyes }\end{array}$ & $\begin{array}{l}\text { Diarrhea in goats and } \\
\text { cattle. Partial blindness } \\
\text { and eye injuries in cattle }\end{array}$ & Bile problems in poultry [40] \\
\hline Kleinia squarrosa & $\begin{array}{c}\text { Aerial } \\
\text { parts }\end{array}$ & An infusion & Diarrhea in poultry & Literature not found \\
\hline Launaea cornuta & $\begin{array}{c}\text { Aerial } \\
\text { parts }\end{array}$ & An infusion & Liver diseases in poultry & $\begin{array}{c}\text { Diarrhea and coccidiosis in } \\
\text { chicken }[1,64]\end{array}$ \\
\hline $\begin{array}{l}\text { Croton } \\
\text { megalocarpus }\end{array}$ & Leaves & An infusion & Liver disease in poultry & $\begin{array}{c}\text { Diarrhea, dysentery, and } \\
\text { swollen heads in poultry [74] }\end{array}$ \\
\hline $\begin{array}{l}\text { Albizia } \\
\text { anthelmintica }\end{array}$ & Bark & $\begin{array}{c}\text { An infusion is administered orally. Dried bark } \\
\text { is ground into a powder which is applied into } \\
\text { eyes }\end{array}$ & $\begin{array}{l}\text { Liver diseases in poultry, } \\
\text { eye injuries in cattle }\end{array}$ & $\begin{array}{c}\text { Deworming and diarrhea in } \\
\text { livestock [64] }\end{array}$ \\
\hline $\begin{array}{l}\text { Plumbago } \\
\text { zeylanica }\end{array}$ & $\begin{array}{l}\text { Roots, } \\
\text { aerial } \\
\text { parts }\end{array}$ & $\begin{array}{l}\text { The roots are burnt and ground into a powder } \\
\text { which is applied into injured eyes. An infusion } \\
\text { from aerial parts is administered orally in } \\
\text { poultry }\end{array}$ & $\begin{array}{c}\text { Eye injury in cattle, lung } \\
\text { and liver diseases in } \\
\text { poultry }\end{array}$ & Literature not found \\
\hline $\begin{array}{l}\text { Cissus } \\
\text { quadrangularis }\end{array}$ & Stem & $\begin{array}{c}\text { An infusion is administered orally. The plant } \\
\text { is sometimes mixed with the bark of } \\
\text { Commiphora baluensis and Albizia } \\
\text { anthelmintica }\end{array}$ & Diarrhea in poultry & $\begin{array}{c}\text { Gall diseases, east coast fever, } \\
\text { lung trouble, and diarrhea in } \\
\text { cattle }[64,65]\end{array}$ \\
\hline $\begin{array}{l}\text { Cissus } \\
\text { rotundifolia }\end{array}$ & Leaves & An infusion & Diarrhea in poultry & $\begin{array}{l}\text { Bloat, black quarter and } \\
\text { anaplasmosis [1] }\end{array}$ \\
\hline Aloe secundiflora & Exudate & An infusion & Diarrhea in poultry & $\begin{array}{c}\text { Coccidiosis in chicken and } \\
\text { diarrhea in livestock }[1,40,64]\end{array}$ \\
\hline
\end{tabular}

health conditions in the study area and in Kitui county at large.

\section{Conclusion and Recommendations}

This documentation contributes to safeguarding the indigenous knowledge of medicinal plants in the study area, which might be useful for the future conservation of such plants in the sanctuary. Efficacy studies of the plant species reported, especially the priority plants are necessary to determine their potential in the development of novel drugs. Further studies are necessary to determine the diversity of plant species sold in the urban areas of Kitui, which might be useful for conservation considerations. The herbalists in the study area need capacity building to develop home gardens for the cultivation of the medicinal plants so as to ease the pressure exerted on wild populations. In addition, government institutions involved in biodiversity conservation in Kenya and the county government need to extend their conservation efforts to the Mutomo hill plant sanctuary. Further studies to determine the suitability of the sanctuary for the conservation of medicinal plants are necessary.

\section{Data Availability}

The data used to support the findings of this study are included within the article.

\section{Conflicts of Interest}

The authors declare that they have no conflicts of interest.

\section{Acknowledgments}

This work was funded by grants from the National Natural Science Foundation of China (31970211), the project of Sino-Africa Joint Research Center CAS (SAJC201614), and CAS-TWAS President's PhD Fellowship Program University of Chinese Academy of Sciences, China. The authors are particularly grateful to Mutomo subcounty rangers and the area subchiefs for introducing them to the herbalists and to the herbalists who participated in their interviews. The authors thank Kitui county government and the Kenya Forest Service for issuing the permits and to the National Museums of Kenya for allowing them to access the East African herbarium.

\section{References}

[1] J. O. Kokwaro, Medicinal Plants of East Africa, University of Nairobi Press, Nairobi, Kenya, 3rd edition, 2009.

[2] A. Gurib-Fakim, "Medicinal plants: traditions of yesterday and drugs of tomorrow," Molecular Aspects of Medicine, vol. 27 , no. 1, pp. 1-93, 2006.

[3] S. van den Geest, "Is there a role for traditional medicine in basic health services in Africa? A plea for a community 
perspective," Tropical Medicine \& International Health, vol. 2, no. 9, pp. 903-911, 1997.

[4] M. Tchicaillat-Landou, J. Petit, C. Gaiani et al., "Ethnobotanical study of medicinal plants used by traditional healers for the treatment of oxidative stress-related diseases in the Congo Basin," Journal of Herbal Medicine, vol. 13, pp. 76-90, 2018.

[5] R. A. Halberstein, "Medicinal plants: historical and crosscultural usage patterns," Annals of Epidemiology, vol. 15, no. 9, pp. 686-699, 2005.

[6] M. F. Mahomoodally, "Traditional medicines in Africa: an appraisal of ten potent African medicinal plants," EvidenceBased Complementary and Alternative Medicine, vol. 2013, Article ID 617459, 14 pages, 2013.

[7] S. Antwi-Baffour, A. I. Bello, D. N. Adjei, S. A. Mahmood, and P. F. Ayeh-Kumi, "The place of traditional medicine in the African society: the science, acceptance and support," American Journal of Health Research, vol. 2, no. 2, pp. 49-54, 2014.

[8] P. Mee, G. R. Wagner, F. X. Gómez-Olivé et al., "Changing use of traditional healthcare amongst those dying of HIV related disease and TB in rural South Africa from 2003-2011: a retrospective cohort study," BMC Complementary and Alternative Medicine, vol. 4, no. 504, pp. 1-13, 2014.

[9] O. Oyebode, N.-B. Kandala, P. J. Chilton, and R. J. Lilford, "Use of traditional medicine in middle-income countries: a WHO-SAGE study," Health Policy and Planning, vol. 31, no. 8, pp. 984-991, 2016.

[10] K. Peltzer, "Traditional health practitioners in South Africa," The Lancet, vol. 374, no. 9694, pp. 956-957, 2009.

[11] W. Musila, D. Kisangau, and J. Muema, Conservation Status and Use of Medicinal Plants by Traditional Medical Practitioners in Machakos District, Kenya, National Museums of Kenya, Nairobi, Kenya, 2002.

[12] J. O. Awiti, "Poverty and health care demand in Kenya," BMC Health Services Research, vol. 14, no. 560, pp. 1-17, 2014.

[13] C. K. Kaingu, J. A. Oduma, and T. I. Kanui, "Practices of traditional birth attendants in Machakos District, Kenya," Journal of Ethnopharmacology, vol. 137, no. 1, pp. 495-502, 2011.

[14] P. A. Nalumansi, M. Kamatenesi-Mugisha, and G. Anywar, "Medicinal plants used during antenatal care by pregnant women in eastern Uganda," African Journal of Reproductive Health, vol. 21, no. 4, pp. 33-44, 2017.

[15] J. M. Nagata, A. R. Jew, J. M. Kimeu, C. R. Salmen, E. A. Bukusi, and C. R. Cohen, "Medical pluralism on Mfangano Island: use of medicinal plants among persons living with HIV/AIDS in Suba District, Kenya," Journal of Ethnopharmacology, vol. 135, no. 2, pp. 501-509, 2011.

[16] N. Mukungu, K. Abuga, F. Okalebo, R. Ingwela, and J. Mwangi, "Medicinal plants used for management of malaria among the Luhya community of Kakamega East subcounty, Kenya," Journal of Ethnopharmacology, vol. 194, pp. 98-107, 2016.

[17] G. N. Njoroge and R. W. Bussmann, "Diversity and utilization of antimalarial ethnophytotherapeutic remedies among the Kikuyus (Central Kenya)," Journal of Ethnobiology and Ethnomedicine, vol. 2, no. 8, pp. 1-7, 2006.

[18] B. O. Owuor, B. A. Mulemi, and J. O. Kokwaro, "Indigenous snake bite remedies of the Luo of western Kenya," Journal of Ethnobiology, vol. 25, no. 1, pp. 129-141, 2005.

[19] B. O. Owuor and D. P. Kisangau, "Kenyan medicinal plants used as antivenin: a comparison of plant usage," Journal of Ethnobiology and Ethnomedicine, vol. 2, no. 9, pp. 1-8, 2006.
[20] C. Posthouwer, "Medicinal plants of kariakoo market, dar es salaam, Tanzania,” M. Sc. Research Project Report, pp. 1-21, Leiden University, Leiden, Netherlands, 2015.

[21] S. McMullin, J. Phelan, R. Jamnadass, M. Iiyama, S. Franzel, and M. Nieuwenhuis, "Trade in medicinal tree and shrub products in three urban centres in Kenya," Forests, Trees and Livelihoods, vol. 21, no. 3, pp. 188-206, 2012.

[22] N. B. Kigomo, "State of forest genetic resources in Kenya," Forest Genetic Working Papers, FAO, Rome, Italy, 2001.

[23] A. Ali and M. Businge, Biodiversity Chapter 4, National Environment Management Authority, Nairobi, Kenya, 2011.

[24] Y. Zhou, B. Liu, Y. Mbuni et al., "Vascular flora of Kenya, based on the flora of tropical East Africa," PhytoKeys, vol. 90, pp. 113-126, 2017.

[25] A. M. Grace, I. Malombe, S. D. Davis, T. R. Pearce, and M. S. J. Simmonds, "Identifying priority species in dryland Kenya for conservation in the millennium seed bank project," Systematics and Conservation of African Plants, pp. 749-758, Kew, London, UK, 2010.

[26] K. Vasisht and V. Kumar, Compendium of Medicinal and Aromatic Plants Africa, Earth, Environmental and Marine Sciences and Technologies, ICS-UNIDO, Area Science Park, Trieste, Italy, 2004.

[27] R. W. Bussmann, "Ethnobotany of the Samburu of Mt. Nyiru, South Turkana, Kenya," Journal of Ethnobiology and Ethnomedicine, vol. 2, no. 35, pp. 1-10, 2006.

[28] P. Jeruto, C. Lukhoba, G. Ouma, D. Otieno, and C. Mutai, "An ethnobotanical study of medicinal plants used by the Nandi people in Kenya," Journal of Ethnopharmacology, vol. 116, no. 2, pp. 370-376, 2008.

[29] M. Kaigongi and F. Musila, "Ethnobotanical study of medicinal plants used by Tharaka people of Kenya," International Journal of Ethnobiology \& Ethnomedicine, vol. 1, no. 1, pp. 1-8, 2015.

[30] K. Kaingu, J. Mbaria, J. A. Oduma, and S. G. Kiama, "Ethnobotanical study of medicinal plants traditionally used in Tana River County for management of illnesses," Asian Journal of Complementary and Alternative Medicine, vol. 2, no. 2, pp. 1-5, 2014.

[31] P. G. Kareru, A. N. Gachanja, J. M. Keriko, and G. M. Kenji, "Antimicrobial activity of some medicinal plants used by herbalists in Eastern Province, Kenya," African Journal of Traditional, Complementary and Alternative Medicines, vol. 5, no. 1, pp. 51-55, 2008.

[32] P. Kareru, G. Kenji, A. Gachanja, J. Keriko, and G. Mungai, "Traditional medicines among the Embu and Mbeere people of Kenya," African Journal of Traditional, Complementary and Alternative Medicines, vol. 4, no. 1, pp. 75-86, 2007.

[33] G. Kigen, Z. Kamuren, E. Njiru, B. Wanjohi, and W. Kipkore, "Ethnomedical survey of the plants used by traditional healers in Narok County, Kenya," Evidence-Based Complementary and Alternative Medicine, vol. 2019, Article ID 8976937, 8 pages, 2019.

[34] D. P. Kisangau, M. K. Kauti, R. M. Mwobobia, T. I. Kanui, and N. K. Musimba, "Traditional knowledge on use of medicinal plants in Kitui County, Kenya," International Journal of Ethnobiology \& Ethnomedicine, vol. 4, no. 1, pp. 1-10, 2017.

[35] J. Nankaya, J. Nampushi, S. Petenya, and H. Balslev, "Ethnomedicinal plants of the Loita Maasai of Kenya," Environment, Development and Sustainability, vol. 22, no. 3, pp. 1-21, 2019.

[36] O. Nanyingi, J. M. Mbaria, A. L. Lanyasunya et al., "Ethnopharmacological survey of Samburu District, Kenya," 
Journal of Ethnobiology and Ethnomedicine, vol. 4, no. 14, pp. 1-12, 2008.

[37] G. Njoroge, "Traditional medicinal plants in two urban areas in Kenya (Thika and Nairobi): diversity of traded species and conservation concerns," Ethnobotany Research and Applications, vol. 10, pp. 329-338, 2012.

[38] G. N. Njoroge and R. W. Bussmann, "Ethnotherapeautic management of skin diseases among the Kikuyus of Central Kenya," Journal of Ethnopharmacology, vol. 111, no. 2, pp. 303-307, 2007.

[39] G. N. Njoroge and R. W. Bussmann, "Ethnotherapeutic management of sexually transmitted diseases (STDs) and reproductive health conditions in central province of Kenya," Indian Journal of Traditional Knowledge, vol. 8, no. 2, pp. 255-261, 2009.

[40] G. N. Njoroge, I. M. Kaibui, P. K. Njenga, and P. O. Odhiambo, "Utilisation of priority traditional medicinal plants and local people's knowledge on their conservation status in arid lands of Kenya (Mwingi District)," Journal of Ethnobiology and Ethnomedicine, vol. 6, no. 22, pp. 1-8, 2010.

[41] S. V. Okello, R. O. Nyunja, G. W. Netondo, and J. C. Onyango, "Ethnobotanical study of medicinal plants used by Sabaots of Mt. Elgon, Kenya," African Journal of Traditional, Complementary and Alternative Medicines, vol. 7, no. 1, pp. 1-10, 2010.

[42] E. O. Omwenga, A. Hensel, A. Shitandi, and F. M. Goycoolea, "Ethnobotanical survey of traditionally used medicinal plants for infections of skin, gastrointestinal tract, urinary tract and the oral cavity in Borabu sub-county, Nyamira County, Kenya," Journal of Ethnopharmacology, vol. 176, pp. 508-514, 2015.

[43] E. Otieno and C. Analo, "Local indigenous knowledge about some medicinal plants in and around Kakamega forest in Western Kenya," F1000Research, vol. 1, no. 40, pp. 1-17, 2012.

[44] M. Pakia, J. A. Cooke, and J. Van Staden, "The ethnobotany of the Midzichenda tribes of the coastal forest areas in Kenya: 2. Medicinal plant uses," South African Journal of Botany, vol. 69, no. 3, pp. 382-395, 2003.

[45] A. Kariuki and G. N. Njoroge, "Ethnobotanical and antimicrobial studies of some plants used in Kibwezi (Kenya) for management of lower respiratory tract infections," African Journal of Traditional, Complementary and Alternative Medicines, vol. 8, no. 2, pp. 144-149, 2011.

[46] P. K. Malonza, A. M. Muasya, C. Lange et al., Biodiversity Assessment in Dryland Hilltops of Kitui and Mwingi Districts, National Museums of Kenya, Nairobi, Kenya, 2006.

[47] S. Zschocke, T. Rabe, J. L. S. Taylor, A. K. Jäger, and J. Van Staden, "Plant part substitution-a way to conserve endangered medicinal plants?," Journal of Ethnopharmacology, vol. 71, no. 1-2, pp. 281-292, 2000.

[48] International Union for Conservation of Nature Natural Resources. Ecosystems, and Livelihoods Group, Conserving Medicinal Species: Securing a Healthy Future, IUCN, Gland, Switzerland, 2006.

[49] P. R. O. Bally, "The Mutomo hill plant sanctuary, Kenya," Biological Conservation, vol. 1, no. 1, pp. 90-91, 1968.

[50] https://thisiskenya.home.blog/counties-of-kenya/kitui-county/.

[51] https://tools.bgci.org/garden_search.php.

[52] H. Hurka, "Conservation genetics and the role of botanical gardens," in Conservation Genetics, V. Loeschcke, S. K. Jain, and J. Tomiuk, Eds., pp. 371-380, Birkhäuser, Basel, Switzerland, 1994.

[53] Y. Morimoto, P. Maundu, D. Tumbo, and P. Eyzaguirre, "How farmers in Kitui use wild and agricultural ecosystems to meet their nutritional needs (Kenya)," Sustainable Use of Biological Diversity in Socio-Ecological Production Landscapes, vol. 52, no. 67, pp. 67-82, 2010.

[54] County Government of Kitui, County Integrated Development Plan 2013-2017: Planning for Sustainable Socio-Economic Growth and Development, County Government of Kitui, Kitui, Kenya, 2014.

[55] E. P. Saggerson, "Geology of the South Kitui area: degree sheet 53, SW quarter, with coloured geological Map," Geological Survey of Kenya, vol. 37, 1957.

[56] E. M. Lind, M. E. Morrison, and A. Hamilton, East African Vegetation, Longman Group Limited, Harlow, UK, 1974.

[57] F. N. Gachathi and J. A. Mullah, "A vital habitat to local livelihood and drought coping strategies in the drylands: the case of Endau Hilltop forest, Kitui district, Kenya," in Proceedings of the Two Workshops: World Agroforestry Centre, Gigiri, Nairobi, KEFRI Research Centre, Kitui, Kenya, S. Eriksen, B. Owuor, E. Nyukuri, et al., Eds., 2005.

[58] R. L. Tignor, "Kamba political protest: the destocking controversy of 1938," African Historical Studies, vol. 4, no. 2, pp. 237-251, 1971.

[59] A. D. Q. Agnew, Upland Kenya Wild Flowers and Ferns: A Flora of the Flowers, Ferns, Grasses, and Sedges of Highland Kenya, Nature Kenya, Nairobi, Kenya, 2013.

[60] H. Beentje, J. Adamson, and D. Bhanderi, Kenya Trees, Shrubs, and Lianas, National Museums of Kenya, Nairobi, Kenya, 1994.

[61] E. Milne-Redhead and W. B. Turrill, Flora of Tropical East Africa, Crown Agents, London, UK, 1952-2012.

[62] F. E. Cook, Economic Botany Data Collection Standard, Royal Botanic Gardens, Kew, Nairobi, Kenya, 1995.

[63] S. Vijayakumar, J. E. Morvin Yabesh, S. Prabhu, R. Manikandan, and B. Muralidharan, "Quantitative ethnomedicinal study of plants used in the Nelliyampathy Hills of Kerala, India," Journal of Ethnopharmacology, vol. 161, pp. 238-254, 2015.

[64] W. Wanzala, M. Syombua, and J. O. Alwala, "A survey of the applications and use of ethnomedicinal plants and plant products for healthcare from the Ukambani region in Eastern Kenya," Indian Journal of Ethnophytopharmaceuticals, vol. 2, no. 2, pp. 6-58, 2016.

[65] W. T. W. Morgan, "Ethnobotany of the Turkana: use of plants by a pastoral people and their livestock in Kenya," Economic Botany, vol. 35, no. 1, pp. 96-130, 1981.

[66] N. Dharani, Field Guide to Common Trees \& Shrubs of East Africa, Penguin Random House South Africa, Cape Town, South Africa, 2011.

[67] J. K. Muthee, D. W. Gakuya, J. M. Mbaria, P. G. Kareru, C. M. Mulei, and F. K. Njonge, "Ethnobotanical study of anthelmintic and other medicinal plants traditionally used in Loitoktok District of Kenya," Journal of Ethnopharmacology, vol. 135, no. 1, pp. 15-21, 2011.

[68] C. W. Lukhoba, M. S. J. Simmonds, and A. J. Paton, "Plectranthus: a review of ethnobotanical uses," Journal of Ethnopharmacology, vol. 103, no. 1, pp. 1-24, 2006.

[69] F. M. Musila, M. Nguta, W. C. Lukhoba, and S. F. Dossaji, "Antibacterial and antifungal activities of 10 Kenyan Plectranthus species in the Coleus clade," Journal of Pharmacy Research, vol. 11, no. 8, pp. 1003-1015, 2017.

[70] R. Mariita, C. Ogol, N. Oguge, and P. Okemo, "Antitubercular and phytochemical investigation of methanol extracts of medicinal plants used by the Samburu community in Kenya," Tropical Journal of Pharmaceutical Research, vol. 9, no. 4, pp. 379-385, 2010. 
[71] D. S. Arora, J. G. Onsare, and H. Kaur, "Bioprospecting of Moringa (moringaceae): microbiological perspective," Journal of Pharmacognosy and Phytochemistry, vol. 1, no. 6, pp. 193-215, 2013.

[72] A. Rani, N. Zahirah, K. Husain, and E. Kumolosasi, "Moringa genus: a review of phytochemistry and pharmacology," Frontiers in Pharmacology, vol. 9, pp. 1-26, 2018.

[73] F. Ngari, R. Wanjau, E. Njagi, and N. Gikonyo, "Herbal materials used in management of oral conditions in nairobi, Kenya," Journal of Oral Health and Community Dentistry, vol. 8, no. 1, pp. 36-42, 2014.

[74] M. M. Gakuubi and W. Wanzala, "A survey of plants and plant products traditionally used in livestock health management in Buuri District, Meru County, Kenya," Journal of Ethnobiology and Ethnomedicine, vol. 8, no. 39, pp. 1-19, 2012.

[75] J. Nankaya, N. Gichuki, C. Lukhoba, and H. Balslev, "Sustainability of the loita Maasai childrens' ethnomedicinal knowledge," Sustainability, vol. 11, no. 5530, pp. 3-13, 2019.

[76] B. Ndemo, "Maasai entrepreneurship and change," Journal of Small Business \& Entrepreneurship, vol. 18, no. 2, pp. 207219, 2005.

[77] C. K. Kaingu, J. A. Oduma, J. M. Mbaria, and S. G. Kiama, "Medicinal plants traditionally used for the management of female reproductive health dysfunction in Tana River County, Kenya," Tang [Humanitas Medicine], vol. 3, no. 2, pp. 1-17, 2013.

[78] C. N. Muthaura, G. M. Rukunga, S. C. Chhabra, G. M. Mungai, and E. N. M. Njagi, "Traditional antimalarial phytotherapy remedies used by the Kwale community of the Kenyan Coast," Journal of Ethnopharmacology, vol. 114, no. 3, pp. 377-386, 2007.

[79] W. Kipkore, B. Wanjohi, H. Rono, and G. Kigen, "A study of the medicinal plants used by the Marakwet Community in Kenya," Journal of Ethnobiology and Ethnomedicine, vol. 10, no. 24, pp. 1-22, 2014.

[80] K. G. Duodu and F. B. Apea-Bah, "African legumes: nutritional and health-promoting attributes," in Gluten-Free Ancient Grains, pp. 223-269, Woodhead Publishing, Cambridge, UK, 2017.

[81] C. H. S. Kabuye, "Edible roots from wild plants in arid and semi-arid Kenya," Journal of Arid Environments, vol. 11, no. 1, pp. 65-74, 1986.

[82] G. N. Njoroge and R. W. Bussmann, "Traditional management of ear, nose and throat (ENT) diseases in Central Kenya," Journal of Ethnobiology and Ethnomedicine, vol. 2, no. 54, pp. 1-9, 2006.

[83] L. K. Keter and P. C. Mutiso, "Ethnobotanical studies of medicinal plants used by traditional health practitioners in the management of diabetes in lower eastern province, Kenya," Journal of Ethnopharmacology, vol. 139, no. 1, pp. 74-80, 2012.

[84] J. Muriuki, Medicinal trees in smallholder agroforestry systems: assessing some factors influencing cultivation by farmers, University of Natural Resources and Life Sciences, Vienna, Austria, Ph.D. Dissertation, 2011.

[85] A. A. Ayantunde, M. Briejer, P. Hiernaux, H. M. J. Udo, and R. Tabo, "Botanical knowledge and its differentiation by age, gender and ethnicity in Southwestern Niger," Human Ecology, vol. 36, no. 6, pp. 881-889, 2008.

[86] C. W. Githinji and J. O. Kokwaro, "Ethnomedicinal study of major species in the family Labiatae from Kenya," Journal of Ethnopharmacology, vol. 39, no. 3, pp. 197-203, 1993.
[87] J. Baylor, Analysis of traditional medicine in Zanzibar, Tanzania: resource conservation and public attitude towards the traditional and alternative medicine policy, pp. 1-40, SIT Graduate Institute, Brattleboro, VT, USA, 2015, Ph.D. Dissertation.

[88] H. M. Amir, O. M. Grace, E. Wabuyele, and M. L. K. Manoko, "Ethnobotany of Aloe L. (Asphodelaceae) in Tanzania," South African Journal of Botany, vol. 122, pp. 330-335, 2019.

[89] E. Wabuyele, Studies on East African aloe species: aspects of taxonomy, conservation and ethnobotany, University of Oslo, Oslo, Norway, Ph.D. Dissertation, 2006.

[90] D. Miziara, "Tuberculosis affecting the oral cavity in Brazilian HIV-infected patients," Oral Surgery, Oral Medicine, Oral Pathology, Oral Radiology, and Endodontology, vol. 100, no. 2, pp. 179-182, 2005.

[91] B. Nalini and S. Vinayak, "Tuberculosis in ear, nose, and throat practice: its presentation and diagnosis," American Journal of Otolaryngology, vol. 27, no. 1, pp. 39-45, 2006.

[92] R. Chavolla, G. F. Dolci, J. F. M. Hernández et al., "Primary tuberculosis of the tonsil," International Journal of Pediatric Otorhinolaryngology Extra, vol. 1, no. 2, pp. 150-153, 2006.

[93] World Health Organization, World Health Statistics 2009, World Health Organization, Geneva, Switzerland, 2010.

[94] J. Davies and D. Davies, "Origins and evolution of antibiotic resistance," Microbiology and Molecular Biology Reviews, vol. 74, no. 3, pp. 417-433, 2010.

[95] J. B. Lucas, E. V. Price, J. D. Thayer, and A. Schroeter, "Diagnosis and treatment of gonorrhea in the female," New England Journal of Medicine, vol. 276, no. 26, pp. 1454-1459, 1967.

[96] S. Yokoi, T. Deguchi, T. Ozawa et al., "Threat to cefixime treatment for gonorrhea," Emerging Infectious Diseases, vol. 13, no. 8, p. 1275, 2010.

[97] A. Koch, P. Tamez, J. Pezzuto, and D. Soejarto, "Evaluation of plants used for antimalarial treatment by the Maasai of Kenya," Journal of Ethnopharmacology, vol. 101, no. 1-3, pp. 95-99, 2005.

[98] J. M. Nguta, J. M. Mbaria, D. W. Gakuya, P. K. Gathumbi, and S. G. Kiama, "Traditional antimalarial phytotherapy remedies used by the South Coast community, Kenya," Journal of Ethnopharmacology, vol. 131, no. 2, pp. 256-267, 2010.

[99] G. M. Rukunga, J. W. Gathirwa, S. A. Omar et al., "Antiplasmodial activity of the extracts of some Kenyan medicinal plants," Journal of Ethnopharmacology, vol. 121, no. 2, pp. 282-285, 2009.

[100] S. N. Wambugu, P. M. Mathiu, D. W. Gakuya, T. I. Kanui, J. D. Kabasa, and S. G. Kiama, "Medicinal plants used in the management of chronic joint pains in Machakos and Makueni counties, Kenya," Journal of Ethnopharmacology, vol. 137, no. 2, pp. 945-955, 2011.

[101] M. Guta, F. F. Teka, D. Bisrat, P. Lindemann, and K. Asres, "Repellent activity of essential oil of the stem of Kleinia squarrosa against mosquitoes," Ethiopian Pharmaceutical Journal, vol. 33, no. 2, pp. 75-82, 2018.

[102] G. Kokwaro, "Ongoing challenges in the management of malaria," Malaria Journal, vol. 8, no. 1, pp. 1-6, 2008.

[103] J. M. Nguta, J. M. Mbaria, D. W. Gakuya, P. K. Gathumbi, and S. G. Kiama, "Antimalarial herbal remedies of Msambweni, Kenya," Journal of Ethnopharmacology, vol. 128, no. 2, pp. 424-432, 2010.

[104] T. Heikkinen and A. Järvinen, "The common cold," The Lancet, vol. 361, no. 9351, pp. 51-59, 2003. 
[105] T. P. Monath, "Yellow fever: an update," The Lancet Infectious Diseases, vol. 1, no. 1, pp. 11-20, 2001.

[106] T. P. Monath, "Treatment of yellow fever," Antiviral Research, vol. 78, no. 1, pp. 116-124, 2008.

[107] B. T. Rouse and A. E. Lukacher, "Some unmet challenges in the immunology of viral infections," Discovery Medicine, vol. 10, no. 53, pp. 363-360, 2010.

[108] C. R. Sudfeld, A. M. Navar, and N. A. Halsey, "Effectiveness of measles vaccination and vitamin A treatment," International Journal of Epidemiology, vol. 39, no. 1, pp. 48-55, 2010.

[109] https://data.unicef.org/topic/child-health/diarrhoealdisease/.

[110] X. Zhang, "Challenges and opportunities in the development of therapeutics for viral infectious diseases in the 21 st century," Virology \& Mycology, vol. 1, no. 1, 2012.

[111] C. D. Kipngeno, S. M. Mshimba, and C. Gilbert, "Antimicrobial activity and phytochemical investigation of crude extracts of the fruits of Solanum incanum (Solananceae) and Dovyalis abbysinica (Flacourtiaceae)," Science Journal of Microbiology, vol. 2014, pp. 1-4, 2014.

[112] D. K Kariuki, J. O. Miaron, J. Mugweru, and L. O. Kerubo, "Antibacterial activity of five medicinal plant extracts used by the Maasai people of Kenya," International Journal of $\mathrm{Hu}$ manities, Arts, Medicine and Sciences, vol. 2, no. 7, pp. 1-6, 2014.

[113] N. Ngoci, M. Ramadhan, M. S. Ngari, and O. P. Leonard, "Screening for antimicrobial activity of Cissampelos pareira L. methanol root extract," European Journal of Medicinal Plants, vol. 4, no. 1, pp. 45-51, 2014.

[114] S. M. Ahmed, H. Nordeng, J. Sundby, Y. A. Aragaw, and H. J. de Boer, "The use of medicinal plants by pregnant women in Africa: a systematic review," Journal of Ethnopharmacology, vol. 224, pp. 297-313, 2018.

[115] C. G. Wagate, J. M. Mbaria, D. W. Gakuya et al., "Screening of some Kenyan medicinal plants for antibacterial activity," Phytotherapy Research, vol. 24, no. 1, pp. 150-153, 2010.

[116] M. M. Kaigongi, S. F. Dossaji, J. M. Nguta, C. W. Lukhoba, and F. M. Musila, "Antimicrobial activity, toxicity and phytochemical screening of four medicinal plants traditionally used in Msambweni district, Kenya," Journal of Biology, Agriculture and Healthcare, vol. 4, no. 28, pp. 6-12, 2014.

[117] W. M. Salem, M. Haridy, W. F. Sayed, and N. H. Hassan, "Antibacterial activity of silver nanoparticles synthesized from latex and leaf extract of Ficus sycomorus," Industrial Crops and Products, vol. 62, pp. 228-234, 2014. 